\begin{abstract}
INSTITUTO DE PSICOLOGIA - DEPARTAMENTO DE PSICOLOGIA ESCOLAR E DO DESENVOLVIMENTO PED

UNIVERSIDADE DE BRASÍLIA
\end{abstract}

CURSO DE ESPECIALIZAÇÃO EM PSICOPEDAGOGIA CLÍNICA E INSTITUCIONAL

TURMA IX

2011/1012

Coordenação: Profa. Dra. Maria Helena Fávero

TRABALHO FINAL DE CURSO

Apresentado por: Maria Aparecida Matos Gordilho

Orientado por: Regina da Silva Pina Neves

BRASÍLIA, 2011 


\section{O TDAH E A APRENDIZAGEM DA MATEMÁTICA: UMA PROPOSTA DE INTERVENÇÃO PSICOPEDAGÓGICA}

Apresentado por: Maria Aparecida Matos Gordilho

Orientado por: Regina da Silva Pina Neves 


\section{ÍNDICE}

I/ Colocação do Problema ............................................................................ 4

II/ Fundamentação Teórica ...................................................................... 7

III/ Método de Intervenção ...............................................................................

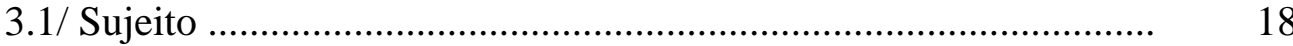

3.2/ Procedimento(s) Adotado (s) ....................................................... 19

IV/ Intervenção Psicopedagógica ................................................................... 21

4.1 / A avaliação psicopedagógica .................................................... 21

- Sessão de avaliação psicopedagógica 01 (27/09/2011) ................... 21

- Sessão de avaliação psicopedagógica 02 (29/09/2011) ................... 23

4.1.1/ Análise das sessões de avaliações .......................................... 25

4.2/ As sessões de Intervenções .......................................................... 27

- Sessão de intervenção psicopedagógica 1 (11/10/2011) ............. 27

- Sessão de intervenção psicopedagógica 2 (20/10/2011) ............. 38

V/ Discussão geral dos resultados das sessões de Intervenção ...................

VI/ Considerações Finais ........................................................................... 50

Referências Bibliográficas .......................................................................... $\quad 52$ 


\section{I/ Colocação do problema}

O problema que motiva esse estudo é o grande número de alunos portadores do Transtorno do Déficit de Atenção e Hiperatividade - TDAH com dificuldades escolares sendo atendidas em consultórios psicológicos, psicopedagógicos ou/e em reforços escolares, com baixo rendimento escolar, principalmente nas compreensões textuais e na matemática. Analisar a relação entre o TDAH e a matemática é instigante por haver poucos estudos sobre o assunto, apesar de inúmeras publicações dos temas isoladamente.

Tal experiência com esses alunos, nos mostra o quanto é angustiante e sofrido tanto para o aluno quanto para a família o lidar ou o não saber lidar com o problema. É sofrido quando o aluno não consegue acompanhar os colegas em sala de aula, é sofrido quando ele acredita que vai lembrar o dever e não anota na agenda, é sofrido quando ele anota na agenda e a perde sem explicação. É muito sofrido quando todos entenderam a explicação do professor em sala de aula e ele não, e, além disso, tem que ficar calado com a dúvida para não se expor aos colegas. É angustiante quando estuda exaustivamente para uma prova, a faz confiante e acredita que se saiu muito bem e quando a nota chega é aquela decepção. É triste ficar sempre de fora dos grupos de trabalhos, porque os outros os vê como incompetente, irresponsável, desligado e bagunceiro.

Meu convívio com alunos TDAHs e com várias situações conflituosas me indigna muitas vezes por perceber o quão desamparado a maioria desses alunos estão, pela escola, que ainda está aprendendo a lidar, pelos amigos que não compreendem e muitas vezes até pela família e sociedade. Me indigna o tanto de cobranças e os castigos que recebem, o quanto são incompreendidos e o quanto são vulneráveis, além de sua autoestima ser normalmente muito baixa.

Além desses problemas normalmente intrínsecos ao TDAH, percebe-se também a dificuldades de compreensão de muitos conceitos em sala de aula, inclusive os matemáticos, o que influencia sobremaneira o caminhar desses alunos. Esse contexto justifica que analisemos pelo menos um deles: a relação dos alunos portadores de TDAH e a matemática, especificamente, a relação com os números decimais.

Conforme Pina Neves (2008, p. iv), estudos brasileiros e internacionais sobre o ensino e a aprendizagem dos conteúdos curriculares dos números racionais, 
destacam que alunos e professores apresentam dificuldades conceituais, sugerindo que o ensino desses conteúdos tem priorizado o uso de regras em detrimento da elaboração conceitual, não ampliando a compreensão dos sistemas numérico e das interações entre as operações e engendrando rupturas conceituais entre os números naturais e os racionais. Além disso, os estudos demonstram que os professores que ensinam matemática não apresentam as competências necessárias para analisar as notações produzidas pelos alunos, e a partir delas elaborar propostas de intervenção, como também comprovam um ensino pautado na ideia de transmissão de conhecimento.

Para entender a relação dos alunos TDAHs e a matemática se faz necessário compreender a natureza do conhecimento, do seu ensino e de sua aprendizagem e como o sujeito se desenvolve. Para isso entendemos assim como Fávero, que:

O ser humano se desenvolve através da construção
dialética da interação e adaptação com o meio
sociocultural, sustentada pelos processos de
internalização e externalização que engendram a tomada
de consciência e para os quais os sistemas de signos são
especialmente importantes, já que se trata de lidar com a
representação (FÂVERO, 2005a; 2009).

Refletindo sobre essa colocação e analisando a relação do aluno portador de TDAH e a matemática, intuímos que durante o seu desenvolvimento, as formas de aquisição desse conhecimento é prejudicada, em vista das características pertencentes ao problema, como desatenção, problema na memória de trabalho e ainda das funções executivas.

Segundo PFROMM (1987), o aprender é uma busca interminável e permanente de discernimento e poder; a passagem de um estado inicial de docilidade à independência, em que numerosos fatores contribuem para a conquista, como diferenças individuais, aptidões, pré-requisitos gerais e específicos, maturação, prontidão, motivação em um processo biológico e ambiental que contrapõem.

Para Piaget, (conforme citado por Fávero, 2005), o conhecimento não se encontra nem no sujeito e nem no objeto, mas na ação que este sujeito exerce sobre o objeto. Isso quer dizer que no processo de construção de conhecimento a mera descrição da realidade não é suficiente. É necessário que se compreenda os estados pelos quais essa realidade se apresenta e as transformações que nela podem ocorrer. Portanto, só é possível o reconhecimento de transformações a partir dos conhecimentos dos estados, 
ao mesmo tempo em que o reconhecimento de cada estado implica o conhecimento das transformações.

Conclui Fávero que, segundo Piaget, o desenvolvimento do ser humano obedece a um movimento que parte da centração (isto é, uma ação de natureza centrada dos objetos) à descentração (isto é, uma ação de natureza descentrada dos objetos e por tanto, abstrata).

Acrescenta PFROMM (1987), que a aprendizagem é uma atividade individual que se desenvolve de um sistema único e contínuo, operado sobre todos os dados recebidos e tornando-os revestidos de significado. Este ato não é limitado à intenção ou ao esforço para reter itens ou habilidades deliberadamente repetidas de momento a momento, mas amplia-se na qualidade do aprendido, no grau de abstração e com o transcorrer da idade.

No âmbito dessa colocação o autor questiona:

\footnotetext{
Então, se a aprendizagem é assim definida, o que é o não aprender, como e por que a criança falha na aprendizagem acadêmica, tendo aparentemente íntegros, todos os processos necessários de aquisição?
}

E quando esses processos não estão totalmente íntegros, como acontece esta aprendizagem? Ampliando mais o quadro e focando os alunos portadores de TDAH e sua relação com a matemática numa perspectiva psicopedagógica é nosso questionamento nessa pesquisa.

Desenvolvemos assim esse esboço, como um recorte dentro da ampla questão da aprendizagem humana, num estudo de caso, tendo nosso trabalho, o objetivo de observar os aspectos que levam a dificuldade escolar e que podem ser detectado através do diagnóstico psicopedagógico, avaliando e intervindo em sessões amparadas por conceituações matemáticas de um sujeito TDAH. 


\section{II/ Fundamentação Teórica}

A psicopedagogia é uma área relativamente nova que parte da confluência de vários campos do conhecimento para análise e compreensão dos problemas de aprendizagens. Atualmente vem ganhando espaço cada vez mais amplo no meio educativo, médico e psicológico.

Para a Associação Brasileira de Psicopedagogia - ABPP, a Psicopedagogia é um campo de atuação em Saúde e Educação que lida com o processo de aprendizagem humana: seus padrões normais e patológicos considerando a influência do meio família, escola e sociedade - no seu desenvolvimento, utilizando procedimentos próprios da Psicopedagogia.

Para Kiguel, "historicamente a Psicopedagogia surgiu na fronteira entre a Pedagogia e Psicologia, a partir das necessidades de atendimentos de crianças com 'distúrbios de aprendizagem', considerada inaptas dentro do sistema educacional convencional" (1991, p. 22).

Weiss (1997), explica que todo o diagnóstico psicopedagógico é, em si, uma investigação, uma pesquisa do que não vai bem com o sujeito em relação a uma conduta esperada. Será, portanto, o esclarecimento de uma queixa, do próprio sujeito, da família e, na maioria das vezes, da escola. No caso, trata-se do não aprender, do aprender com dificuldade ou lentamente, do não revelar o que aprendeu, do fugir de situações de possível aprendizagem.

De posse desses entendimentos, encontramos na psicopedagogia o aporte teórico e metodológico que buscávamos na compreensão das limitações e das competências apresentadas pelos alunos em situação escolar ou extraescolar, em especial os portadores de TDAHs. Além disso, interessa-nos investigar tal situação no contexto de conceituação matemática. Para tanto, desenvolvemos a seguir aspectos teóricos sobre a aprendizagem matemática no que se refere às operações aritméticas fundamentais e o TDAH.

Contribuindo para essa compreensão Barkley (2008), afirma que o TDAH é o atual rótulo diagnóstico usado para denominar os significativos problemas apresentados por crianças quanto à atenção, tipicamente com impulsividade e atividade excessiva. Conforme o autor é um transtorno neurobiológico, originário nas principais atividades executivas da vida, desde a infância, passando pela adolescência e até a vida 
adulta. E ainda, que o TDAH hoje é reconhecido como um transtorno universal, com aceitação internacional cada vez maior para sua existência, como condição debilitante crônica, para a qual se deve combinar medicação e ajuda psicossociais para seu tratamento.

O TDAH compreende um problema com a inibição comportamental (executiva), enquanto sugere que os problemas da atenção associados ao transtorno provavelmente representem déficits em domínios neuropsicológicos mais amplos do funcionamento executivo, em especial a memória de trabalho. (BARKLEY, 2008).

Muito tem se falado na função executiva do cérebro, como também na memória de trabalho do portador do TDAH. Conforme Rhode e Mattos (2003), a função executiva compreende uma classe de atividades altamente sofisticadas, que capacitam o individuo ao desempenho de ações voluntárias, independentes, autônomas, auto organizadas e orientadas para metas específicas. Os portadores de TDAH no seu cotidiano têm dificuldades para tomar iniciativas, especialmente sem estímulo externo, planejarem, estabelecer prioridades e organizar-se para o trabalho e ainda, sonolência diurna, baixa tolerância à frustração, lentidão e falta de monitoramento com relação ao tempo. Tudo isso requer muito das funções executivas do cérebro.

O comprometimento da memória de trabalho confirma o autor, é manifestado na dificuldade de manter eventos em mente, manipulá-los ou agir de acordo com eles. Manifesta-se, também na dificuldade de antecipar consequências futuras, na diminuição de sentido de tempo e da organização temporal das ações.

Problemas com a memória de trabalho são muito encontrados no portador de TDAH, atrapalhando o aluno em sala de aula, principalmente na lentidão na aprendizagem da matemática, das ciências e da leitura, ou seja, aprendizagem em que requerem armazenamento, processamento de informações.

Outra dificuldade na função executiva, no aluno com TDAH é a de selecionar, alternar e manter a atenção numa tarefa. Dessa forma, os alunos com TDAH, querem realizar tudo de uma só vez, não conseguem se organizar e ordenar suas tarefas por prioridades e têm a atenção mantida por pequenos intervalos de tempos. O monitoramento das ações e as auto avaliações, também são comprometidas, acarretando inabilidade em perceber os erros e também dificuldades de percepções sociais. Os 
alunos TDAHs muitas vezes saem de uma prova com a certeza de que foram bem, quando na verdade não foram.

Conforme Rhode e Matos (2003), o crescente número de repetência no ensino fundamental, a distorção idade série em sala de aula, e também o aumento de encaminhamentos de alunos, solicitando que recebam atendimentos especializados, têm levado muitos estudantes a uma baixa autoestima, ao desestímulo em seus estudos. E o desinteresse causado pela dificuldade em prestar atenção, e em se centrar para entender o que está sendo estudado, tem elevado o índice dessas crianças à repetência e a, entenderem que a organização da escola, e da sala de aula não está contemplada a sua realidade, levando-os a abandoná-la.

Outro aspecto importante também a ser considerado é o relacionado com os problemas cognitivos, conforme Barkley (2008), já não há mais dúvida de que crianças portadoras do TDAH apresentam níveis inferiores de desempenho intelectual do que crianças comuns, refletindo diretamente nas realizações acadêmicas (a produtividade do trabalho na sala de aula e o nível de dificuldade daquilo que as crianças já aprenderam e dominaram). Acredita-se, conforme o autor, que esse desempenho fraco resulte do comportamento desatento, impulsivo e inquieto em sala de aula, melhorado muito quando o aluno faz uso de medicamentos estimulantes. Mesmo assim, as crianças portadoras de TDAH apresentam desempenho inferior ao de seus colegas em testes de leitura, matemática e compreensão da leitura. Dessa forma, o autor conclui que:

\footnotetext{
Por conta desses déficits em habilidades acadêmicas, não é de surpreender que até $56 \%$ das crianças com TDAH possam necessitar de monitores acadêmicos, que aproximadamente $30 \%$ possam repetir a série na escola, e que 30 a $40 \%$ sejam colocados em um ou mais programas de educação especial.
}

Levando esses aspectos em consideração e agregando a eles a forma que o professor transmite o conteúdo em sala de aula, passamos a refletir e hipotetizar que a aprendizagem dos conteúdos de matemática, pode ser prejudicada em função da presença do TDAH. Visto que muitos problemas relacionados ao entendimento desses alunos, é justificado pela forma que os mesmos são recebidos por eles. Considerando ainda a existência das dificuldades de entendimento dos conteúdos devido às próprias características da disciplina, não se pode dessa forma patologizar e procurar culpados e 
sim enfatizar que existe uma cultura engendrada em torno da matemática, como sendo matéria de difícil apreensão (Correa \& MacLean, 1999).

Particularmente com relação à matemática, ela está presente no nosso cotidiano e sem nos darmos conta. Lidamos o tempo todo com ela desde muito cedo, em várias situações do dia-a-dia e em diversos contextos: em casa, na rua, na escola. Conforme Piaget, (citado por Fávero, 2005), desde que nascemos, ao agirmos sobre as coisas ao nosso redor, classificamos essas coisas, relacionando-as segundo um critério qualquer, seja no início, dentro de um critério dado pelas suas características físicas (coisas quadradas, duras, lisas etc.), em resumo, nós operamos.

E a escola tem o papel de propiciar aos alunos ao longo dos anos o aprendizado pleno da disciplina. Dessa forma, os conceitos são gradativamente introduzidos, de modo que ao final do $5^{\circ}$ ano do ensino fundamental, conforme os Parâmetros Curriculares Nacionais - PCNS (1997), o aluno tenha conhecimentos sólidos sobre números naturais, sistema de numeração decimal e números racionais, operação com números naturais e racionais entre outros.

No entanto, quando na resolução de situações problema no contexto escolar, muitos alunos falham em relação ao reconhecimento e utilização dos procedimentos algorítmicos adequados.

Confirmando a informação, os PCNS (1997), trazem a afirmação de que o estudo com números racionais na forma decimal pode ser facilitado se os alunos forem levados a compreender que as regras do sistema de numeração decimal, utilizada para representar os números naturais, podem ser estendidas para os números racionais na forma decimal e, além disso, que:

\footnotetext{
As situações com números decimais estejam envolvidas em situações contextualizadas, de modo que possa se fazer uma estimativa ou enquadramento do resultado, utilizando números naturais mais próximos (BRASIL 1997, p 80).
}

Chernay (2001), afirma que um dos desafios essenciais e ao mesmo tempo uma das dificuldades principais do ensino da matemática, é precisamente que o conteúdo esteja carregado de significados, que tenha sentido para o aluno. 
Brousseau (1996) confirma os ditos de Chernay, dizendo que "compreender" é ser capaz de reconhecer as ocasiões de utilizar o conhecimento e de aplicá-lo em novos domínios, e ainda que o aluno que pode "compreender", pode "raciocinar" a respeito de seu saber, analisá-lo ou combiná-lo com outros.

Nunes (1991) acrescenta que as abordagens com números racionais decimais devem partir de uma conexão entre o conhecimento cotidiano e o conhecimento escolar. E esse pode ser o ponto de partida para novas formas de ensino na escola.

Stone, (citado por Chaga, 2004), justifica que a matemática é considerada como a mais antiga das ciências e, como matéria ensinada, faz parte dos currículos escolares há mais de dois mil anos, tendo ocupado um lugar privilegiado, esclarecendo dessa forma, sobre a razão do privilégio que lhe é atribuído.

Privilégio esse que faz com que a disciplina seja considerada "o bicho papão" dos alunos de um modo geral, sendo também, conforme Chaga (2004), a disciplina que mais reprova, retendo os alunos sucessivas vezes na mesma série e, portanto causando grande número de evasões escolares, especialmente no ensino fundamental.

Umas das explicações para este fato estão nos escritos de Medeiros (citado por Pina Neves, 2008), mostrando que o ensino de matemática, continua na sua maioria, sendo realizado pela transmissão de saberes prontos pelos professores aos alunos, em todos os níveis de ensino; que os professores da Educação Básica, na maior parte dos casos, são usuários de regras e vivenciaram em sua formação inicial, um ensino também pautado na transmissão de saberes. Além disso, pontuavam que as dificuldades enfrentadas pelos alunos relacionavam-se à preocupação excessiva por parte dos professores, com o treino de habilidades e mecanização de algoritmos; memorização de regras de resolução de problemas, com predomínio de repetição e imitação; e, por parte dos alunos, de estratégias apresentadas em sala de aula pelos professores.

Outra justificativa é discutida em Chaga (2004), acrescentando que o problema refere-se ao fato de que a matemática é frequentemente tratada como sendo uma área do conhecimento humano desligada da realidade e do cotidiano onde o individuo encontra-se inserido. Sendo assim, é comum ouvirmos questionamentos dos alunos: Para que vou estudar isso? Onde vou usar isso na minha vida? Para que serve 
este conhecimento? Muitas vezes essas perguntas nem são respondidas, porque na realidade, em algumas situações, nem o professor sabe.

Chaga (2004) acrescenta que em escolas onde professores de matemática trabalham com o ensino tradicional, pode-se observar que o processo ensino aprendizagem dos alunos torna-se mera transmissão da matéria, ou seja, o professor "transmite" e os alunos "recebem". Esta atividade puramente mecanizada de exercícios acarreta, por partes dos alunos, futura memorizações de como estes exercícios foram inicialmente desenvolvidos.

Outro fator presente em nossas escolas que afeta o aprendizado da matemática destacado pela a autora, se refere ao fato de muitos professores possuírem excessiva preocupação em apenas "vencer" o conteúdo e também a falta de cuidado dos professores na verificação se realmente os alunos encontram-se preparados para enfrentarem assuntos novos a serem transmitidos pelo professor.

Macedo (conforme citado em Pina Neves, 2008), acrescenta que o mais importante a ser observado nesse processo de ensino-aprendizagem, é saber como ensinar e como os alunos aprendem. Nesse sentido, é preciso ter domínio sobre os processos de aprendizagem, é preciso saber o que se aprende; e, além disso, ter domínio sobre os procedimentos de ensino, sendo planejados com base no conhecimento de como a aprendizagem se processa. Desse modo, ser competente no ensino requer, pelo menos, dois domínios: um sobre os procedimentos de aprendizagem e outro sobre o de ensino. Além disso, para que o professor recentre sua atenção no ato de aprender, é preciso que ele domine não só o objeto a ser conhecido, sua gênese e suas lógicas, como também as abordagens mais indicadas.

Fávero (2005) corrobora a afirmação de Macedo, pontuando que é imprescindível admitir que não só os professores como também seus alunos estão em processos de mudanças, o que significa, a partir da ótica das várias teorias da psicologia do desenvolvimento, considerar que esses sujeitos estão em desenvolvimento e que [ ] desenvolver significa evoluir e evoluir significa ascender na escala natural... E que o ser humano é ativo, construtor de ideias, construtor da história humana e, portanto, construtor do seu desenvolvimento.

Isso significa para a autora que a escola, assim como as outras situações nas quais está envolvida, a relação entre o sujeito humano e a aquisição de conhecimento 
tem-se mantido "impermeável” às transformações pelas quais a própria concepção de ciência tem passado por transformações estas que mantêm uma relação dialética com a sua própria construção e que:

\begin{abstract}
As disciplinas relacionadas às diferentes áreas do conhecimento são tratadas como "pacotes" fechados, nos quais a formalização obedece a regras préestabelecidas, em detrimento dos significados conceituais, pacotes esses que os alunos devem se esforçar para absorver (FÁVERO, 2005).
\end{abstract}

Tais fatos levam-nos ao entendimento que deva haver uma ruptura do ensino de matemática do modelo tradicional e outras maneiras devam ser experienciadas por professores em sala de aula. Optar por um modelo construtivista, por exemplo, pode ser uma proposta. É claro que não pode se tomar uma teoria como verdade absoluta, conforme Moreira (2007), o conhecimento é sempre relativo e uma teoria é sempre limitada. Por isso, uma teoria deve servir como uma possibilidade entre tantas, de construção de educação diferenciada.

Outro aspecto a ser levado em consideração é a relação professor-aluno, e a afetividade existente nessa relação. Fernandes, (conforme citado por Moreira 2007) argumenta que para ocorrer uma situação de aprendizagem deve-se estabelecer uma relação entre ensinante e aprendente e destes com o conhecimento.

Segundo Weiss (1997), a prática psicopedagógica deve considerar o sujeito como o todo, constituídos pelos aspectos afetivos, cognitivos, orgânicos, pedagógico e social. $\mathrm{O}$ aspecto afetivo diz respeito à relação entre o desejo de aprender e a afetividade do sujeito, pois o mesmo pode não estabelecer um vínculo positivo com a aprendizagem. $\mathrm{O}$ aspecto cognitivo está intimamente relacionado às estruturas do pensamento do sujeito, pois atividades escolares podem exigir do sujeito estágios não compatíveis com o desenvolvimento dessas estruturas. O aspecto pedagógico está relacionado à avaliação, ao método, aos conteúdos, à prática docente etc. Por último o aspecto social está relacionado à interação do sujeito com a família, com a sociedade, bem como seu contexto sócio-cultural.

Para a autora, a dificuldade de aprendizagem representa a relação inadequada dos aspectos apresentados ou o funcionamento insatisfatório de cada um desses aspectos. 
Diante de tudo isso, compreendemos que nem todos os alunos possuem as mesmas competências para lidar com determinada área de conhecimento e seus conceitos. Este fato pode estar atrelado a vários fatores, inclusive ao TDAH e que os motivos para que devam existir várias maneiras de ensinar é por existir várias maneiras de aprender.

Sendo assim, nosso trabalho assume o desafio de promover o desenvolvimento conceitual em matemática junto a um estudante de Ensino Fundamental com TDAH, entendendo como possível a conceituação matemática e assumindo que a mediação é ponto central nesse processo. 


\section{III/ Método de Intervenção}

O método de intervenção adotado nesse estudo está em consonância com os aportes teóricos da Psicologia do Desenvolvimento, em especial, os discutidos por Visca (1991); Fávero (2005a); Pina Neves (2008); Weiss (1987), entre outros.

Visca (1991) defende o método de intervenção na Epistemologia Convergente que propõe um trabalho clínico utilizando-se da articulação de três linhas teóricas: a psicogenética de Piaget, onde, ninguém é capaz de aprender além do que permite sua estrutura cognitiva, a psicanalítica freudiana, onde dois sujeitos com igual nível cognitivo e distintos investimentos afetivos em relação a um objeto aprenderão de forma diferente e a psicologia social de Enrique Pichon Rivière, que fala que se houver uma paridade do cognitivo e afetivo em dois sujeitos de distinta cultura, também suas aprendizagens em relação a um mesmo objeto seriam diferentes, devido às influências que sofreram pelos meios socioculturais (VISCA, 1991, p. 66).

Para Visca (1987), a aprendizagem depende de uma estrutura onde envolva o cognitivo, o afetivo e o social, na qual esteja indissociavelmente ligada a algum aspecto desses três elementos. Dessa forma a inteligência se constrói a partir da interação do sujeito e as circunstâncias sociais.

Nessa perspectiva, a Teoria Convergente integra três teorias, nos possibilitando a reflexão sobre as mais diversas causas dos problemas de aprendizagem e nos remetendo a perceber que a aprendizagem depende do organismo, pois o aluno aprende com ou sem professor, assim o próprio ambiente é quem transforma e o controla.

Nosso objetivo nessa investigação foi perceber nossa responsabilidade em detectar se as situações descritas, tanto nas dificuldades do aluno TDAH como às encontradas na matemática estão influenciando no processo de aquisição da aprendizagem do aluno, demonstrando a necessidade de ampliação de o nosso olhar para um mundo das possibilidades no diagnóstico de possíveis causas, assumindo o posicionamento de Visca que diz:

Eu acho que a aprendizagem, para uma pessoa, abre caminho da vida, do mundo, das possibilidades até de ser feliz... (VISCA, 1991, P. 18).

Ficou claro ainda pelos embasamentos teóricos de Weiss (1997), que trás uma visão diagnóstica dos problemas de aprendizagem escolar e descreve que para se 
iniciar uma avaliação psicopedagógica é fundamental que o terapeuta tenha claro dois grandes eixos de análise:

- HORIZONTAL - A HISTÓRICO - VISÃO DO PRESENTE, “AQUI, AGORA, COMIGO”.

- VERTICAL - A HISTÓRICO - VISÃO DO PASSADO, VISÃO DA CONSTRUÇÃO DO SUJEITO.

Conforme a autora, no eixo horizontal explora-se o campo presente, onde a busca está centrada nas causas que coexistem temporariamente como sintoma. Nesse nível é que se realiza a contextualização, que permite clarificar a grandeza do desvio existente com o paciente. No eixo vertical, histórico, é onde se busca a construção geral do indivíduo, sempre contextualizada nos diferentes momentos.

Para cumprir esses objetivos, foi utilizada em nossa investigação, além da entrevista com a responsável do aluno, a anamnese - Weiss (1987), entrevista Operativa Centrada na Aprendizagem - E.O.C.A. - Visca, (1987), sessões lúdicas, com jogos matemáticos, como: dominós, de adição e subtração, ábaco, encarte de supermercado, dinheirinho de brinquedo e outros.

Adotou-se, a entrevista semiestruturada, as anotações feitas pelo aluno e a gravação como instrumentos de coleta de dados. Após a entrevista e as sessões de avaliação e intervenção, passou-se à organização da análise, formulando hipóteses e elaborando indicadores que fundamentariam a interpretação final, refletindo sobre os questionamentos da pesquisadora e as manifestações fornecidas pelo referencial teórico.

Iniciamos nosso estudo, com a primeira sessão de avaliação, chamada de anamnese, descrita por Weiss (1987) como um dos principais pontos para um bom diagnóstico, pois possibilita a integração do passado, presente e projeções para o futuro do sujeito, permitindo perceber a inserção na sua família e a influência das gerações passada neste núcleo e no próprio aluno. Na anamnese, é levantado dados das primeiras aprendizagens, evolução geral do sujeito, história clínica, história familiar, nuclear, evolução geral do sujeito, história das famílias materna e paterna e historia escolar.

A segunda sessão, chamada por Visca (1987) de EOCA, é uma entrevista operativa focada na aprendizagem. Não é rígida, podendo variar segundo as circunstâncias. É um instrumento simples e rico em seus resultados. 
As sessões seguintes, sessões de intervenção, chamadas por Weiss (2008), de sessões lúdicas centradas na aprendizagem, descritas pela a autora como fundamentais para a compreensão dos processos cognitivos, afetivos e sociais, e sua relação com o Modelo de Aprendizagem do Sujeito.

Seguindo esse modelo, algumas alterações foram feitas, quando necessário, para melhor observação do aluno e assim alcançar o seu "Modelo de Aprendizagem". Permitindo-nos refletir e levantar hipóteses sobre os problemas detectados que interferem na aprendizagem, nos dando subsídios para inferências.

Modelo de Aprendizagem é um conjunto dinâmico que estrutura os conhecimentos que o sujeito já possui, os estilos usados nessa aprendizagem, o ritmo e área de expressão da conduta, a modalidade e o funcionamento cognitivos, os hábitos adquiridos, as motivações presentes, as ansiedades, defesas e conflitos em relação ao aprender, as relações vinculares com o conhecimento em geral e com os objetos de conhecimento escolar, em particular, e o significado da aprendizagem escolar para o sujeito, sua família e a escola (WEISS, 1997, p.32).

Dessa forma, avaliamos que o método de intervenção psicopedagógico, proposto por Visca, (1987) descrito acima, nos auxiliou na busca de nossos objetivos e em nossos entendimentos sobre o estudo de caso do aluno TDAH e sua relação com os conceitos matemáticos. Instrumentalizou-nos para intervir no que supomos e descrevemos anteriormente como sendo contribuidores da dificuldade percebida, nos capacitando a sugerir novos caminhos a serem trilhados por professores e alunos, na busca de desenvolvimento de ambos.

Chaga (2004), afirma que o ensino da matemática é mera transmissão da matéria, com atividades mecanizadas servindo basicamente para memorizar o que já foi anteriormente desenvolvido e que os professores que trabalham com o ensino tradicional acabam engessando o ensino, como confirma Fávero (2005b), acrescentando que a disciplinas é como se fosse pacotes fechados, onde os alunos devem ser esforçar para aprender. Mostrar ao aluno que o estudo da matemática pode acontecer de forma diferente, de forma interessante, motivadora, dinâmica e divertida. Desmistificando assim, o engendramento de que a matemática é um "bicho papão".

Assim, diante desse contexto adotamos a Intervenção Psicopedagógica na perspectiva proposta em Visca (1987), Fávero (2005b), Pina Neves (2008) e Weiss 
(1997), tendo como sujeito um aluno do $5^{\circ}$ ano do ensino fundamental, portador do Transtorno do Déficit de Atenção e Hiperatividade TDAH.

\section{1/Sujeito}

O sujeito observado é P., um pré-adolescente de 11 anos de idade, cursando o $5^{\circ}$ ano do Ensino Fundamental, bolsista de uma escola particular de Brasília, Distrito Federal. Frequenta a escola no turno matutino e participou das sessões no turno vespertino. O acesso a ele foi feito por meio de triagem entre 28 alunos em um Apoio pedagógico e psicopedagógico. Esse espaço que colaborou com nossa pesquisa, é um lugar aconchegante, acolhedor e tem como meta o desenvolvimento do raciocínio: o trabalho é feito com os processos de pensamento necessários ao ato de aprender. Os jogos são muito utilizados, por serem férteis no sentido de criarem um contexto de observação e diálogo sobre os processos de pensar e construir o conhecimento. Este procedimento promove um desenvolvimento cognitivo maior do que aquele que as escolas costumam conseguir. Tem como meta também ajudar os alunos na apropriação dos conteúdos escolares, visando propiciar o domínio das disciplinas escolares em que o aluno não vem tendo um bom aproveitamento.

Diferenciando-se do professor particular, pois o conteúdo escolar é usado apenas como estratégia para ajudar a fornecer ao aluno o domínio de si próprio e as condições necessárias ao desenvolvimento cognitivo; e ainda recebe uma demanda que normalmente tem dificuldades de acompanhar as rotinas escolares e os conteúdos, como por exemplos atendimentos a alunos com dificuldades intelectuais, transtornos globais do desenvolvimento, tdah, dislexia e outros, sempre relacionado com o contexto escolar. A referida sala de apoio localiza-se nas próximidades da escola e já atende o aluno duas vezes por semana, auxiliando-o em suas necessidades e propostas descritas.

O Aluno de nossa pesquisa tem o diagnostico do Transtorno do Déficit de Atenção e Hiperatividade (TDAH) e faz uso do medicamento metilfenidato desde que tinha seis anos de idade, quando na ocasião, apresentava comportamento de inquietação, era disperso, não conseguia se concentrar e seu rendimento escolar em matemática era baixo. Foi selecionado para participar desse estudo por agregar características que correspondem ao nosso interesse de estudo: ser portador do TDAH, fazer uso da 
medicação metilfenidato, apresentar dificuldades escolares, principalmente em matemática e estar matriculado no ensino fundamental.

A responsável por $\mathrm{P}$ foi consultada sobre o desenvolvimento do estudo e o mesmo pôde ser realizado com sua autorização.

P mora com a tia paterna, desde 07 anos de idade, quando a mesma conseguiu na justiça sua guarda e de sua irmã. Ele é gentil, gosta de animais como dinossauros, revistas em quadrinhos, videogames. Apresenta baixo rendimento escolar, principalmente em matemática. Tem autoestima elevada, se acha bonito, gosta do seu cabelo cacheado, diz que faz amizade com facilidade, se diz ser o terceiro mais popular da sala de aula, que os professores gostam dele porque ele faz todos os deveres de casa, anota os deveres na agenda e ainda ajuda os colegas quando necessário. Acha-se inteligente porque, conforme ele, sempre consegue notas boas, fato que não corresponde a realidade, quando confrontamos com o boletim e relato da tia.

Com relação à escola, $\mathrm{P}$ tem um vínculo bem estabelecido, gosta do ambiente e de suas relações. Quando se trata das disciplinas de um modo geral, diz preferir a matéria de ciências porque trata dos animais e da natureza, mas não gosta muito de matemática, porque diz esquecer com facilidade o que o professor explica em sala de aula e ainda que é difícil de compreender, pois quando ele acaba de aprender um número, já tem que aprender outro e nunca acaba de aprender.

P deixa de anotar muita coisa na agenda e também não entrega os deveres em dia, apesar do acompanhamento que faz, pois, sem informações na agenda, não se sabe ao certo o que foi passado em sala de aula. Tal situação gera problemas quanto ao seu desenvolvimento na escola.

\section{2/ Procedimento(s) Adotado(s)}

Foram realizadas quatro sessões psicopedagógicas individualmente, assim organizadas: a primeira com a tia, responsável legal e as demais com $\mathrm{P}$, na sala de Apoio Pedagógico e Psicopedagógico, com duração de 90 minutos cada, aproveitando o tempo que o aluno permanecia no local, tendo ocasiões em que a sessão precisou ser prolongada em função da atividade proposta. As sessões foram previamente agendadas com a responsável, que seriam duas vezes por semana, na terça e na quinta-feira, dia em que $\mathrm{P}$ faz acompanhamento, mas houve alteração de data, em vista do não 
comparecimento do aluno no dia combinado. As sessões foram remarcadas e realizou-se nas terças e quintas-feiras da semana seguinte, e assim sucessivamente até o término da intervenção.

Combinamos que sempre que ele precisasse poderia usar papel e canetas disponibilizadas sobre a mesa. Solicitando que, ao errar, não rasurasse a questão e sim começasse outra vez o seu registro para não perdermos nada que fosse anotado. As sessões foram filmadas com a permissão da responsável e transcritas pessoalmente pela pesquisadora para a pesquisa. 


\section{IV/ Intervenção psicopedagógica:}

\section{1/ Primeira Sessão de Avaliação}

A primeira sessão de avaliação foi realizada em 27 de setembro de 2011, nas dependências do apoio pedagógico e psicopedagógico, no qual o aluno faz acompanhamento, com duração de aproximadamente duas horas. Participaram desta sessão a pesquisadora e a responsável do pré-adolescente.

\section{- Objetivo}

Conhecer a história de vida do aluno.

\section{- Procedimentos}

Foi realizada uma entrevista semi-estruturada, numa conversa informal, sem ficar presas à perguntas e respostas. A entrevistada era incentivada a falar sobre o que conhecia do sujeito espontaneamente, sem preocupação com o tempo, somente seguíamos a sequência de coleta de dados no computador, previamente estruturada pela entrevistadora.

A tia, irmã do pai biológico, é atualmente a responsável legal de $\mathrm{P}$, que nasceu em uma familia desestruturada e de dependentes químicos. Tanto o pai como a mãe faziam uso de entorpecentes e bebidas alcoólicas. A mãe quando engravidou de $\mathrm{P}$, segundo filho dela, já era viciada e durante a gravidez bebia muito e usava drogas. Na gestação, a mãe teve toxoplasmose.

$\mathrm{P}$ nasceu com baixo peso e apresentava característica físicas alteradas: cabeça muito grande e pouca estatura. $\mathrm{P}$ foi desenganado pelos médicos e depois de mais ou menos trinta dias na Unidade de Terapia Intensiva - UTI, quando recebeu alta do hospital.

P não mamou e nem teve os cuidados primários da mãe. A avó assumiu a responsabilidade sobre ele e sua irmã, quando então foram morar em sua casa. A mãe de $\mathrm{P}$ faleceu quando ele tinha 4 anos de idade. Ele ficou morando com o pai e a avó paterna até sete anos, quando a tia conseguiu na justiça sua guarda e de sua irmã.

O pai, mesmo com problemas de vício, percebeu que o $\mathrm{P}$ com cinco ou seis anos, apresentava dificuldades escolares e procurou ajuda neurológica, quando P foi 
diagnosticado com o TDAH. Ele começou a tomar medicação com essa idade, mas logo o tratamento foi interrompido, retornando só quando já estava morando com a tia, então com 9 anos.

Atualmente $\mathrm{P}$ continua estudando na mesma escola, mora com a tia, sua irmã e uma prima, os problemas escolares são muitos, suas notas são baixas, principalmente em matemática. 


\section{Segunda Sessão de Avaliação}

A segunda sessão, foi realizada em 29 de setembro de 2011, nas dependências do apoio pedagógico e psicopedagógico, no qual o aluno faz acompanhamento, com duração de aproximadamente 50 minutos. Participaram desta sessão a pesquisadora e o sujeito de estudo.

\section{- Objetivo}

Verificar o conhecimento de $\mathrm{P}$ sobre os números naturais, relação de número e quantidade, sequência numérica crescente e decrescente, adição, subtração. Como também verificar a estratégia utilizada no jogo e seus modos de atenção e concentração.

\section{- Procedimentos}

Alguns jogos de matemática, foram dispostos sobre uma mesa redonda, como: jogo das quatro operações, jogo da memória de adição e subtração e dominós de adição, subtração, multiplicação e divisão. P sentava numa cadeira que o deixava confortável com relação a altura da mesa. Nossa opção foi por começar jogando o jogo de dominó de adição e depois, o de subtração. Ele ficou à vontade para conhecer o jogo, manipulou as peças e mostrou-se interessado em jogar.

Embaralhamos as peças e cada um pegou 7. Falei com ele que gostava de jogar com as minhas peças viradas para cima, pois achava mais fácil de encontrar a resposta correta. Na verdade queria que ele virasse as dele também para que eu pudesse observar quando ele passava a vez, se ele tinha a peça na mão e ainda para verificar se ele estava fazendo a conta corretamente. Seguindo as intruções, foi sugerido a ele que colocase suas peças em ordem crescente, de cima para baixo, pois ficava melhor a visualização. Ele atendeu a sugestão corretamente, me fazendo observar que possuia entendimento de em cima e embaixo e também de ordem crescente.

$\mathrm{P}$ começou a jogar sem dúvidas sobre o jogo, usava seus dedos para contas mais altas e sempre colocava a peça no jogo corretamente, adicionava sem apresentar nenhuma dificuldade. $\mathrm{O}$ jogo durou mais ou menos 10 minutos, as regas foram bem entendidas e chegamos ao final do mesmo com $\mathrm{P}$ bastante estimulado, pois, ganhou a 
partida. Foi com a mesma motivação para o segundo jogo, que era dominó de subtração ${ }^{1}$.

No segundo jogo, logo na primeira jogada ele ficou muito pensativo, não conseguia subtrair $(23-6)$. Depois de um tempo, sem mediação, ele falou a resposta corretmanete: "dezessete".

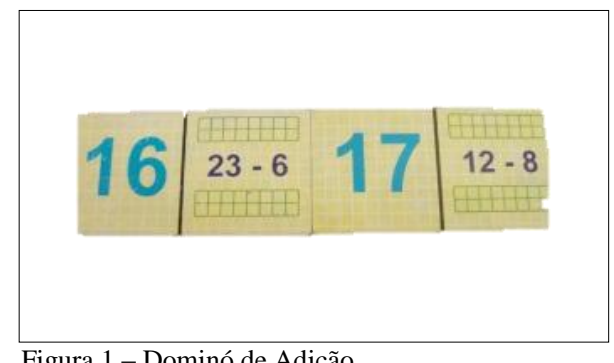

Quando questionado de como tinha chegado ao resultado, ele falou que tinha partido do 23 e foi diminuindo nos dedos até chegar ao 17. Uma intervenção foi realisada nesse momento, explicando se ele tinha dificuldade com a subtração, que ele podia continuar usando a adição, já que a segunda é o inverso da primeira. Sendo assim ele poderia, ao invés de subtrair $23-6=17$, somaria $6+17=23$. P tentou seguir o que foi sugerido, mas não conseguia, se atrapalhava na subtração e quando tenta somar para verificar se o resultado estava correto, se confundia e não chegava ao resultado certo.

Em vista de persistirem as dificuldades com as subtrações, foi sugerido o uso do ábaco ${ }^{2}$ como recurso.

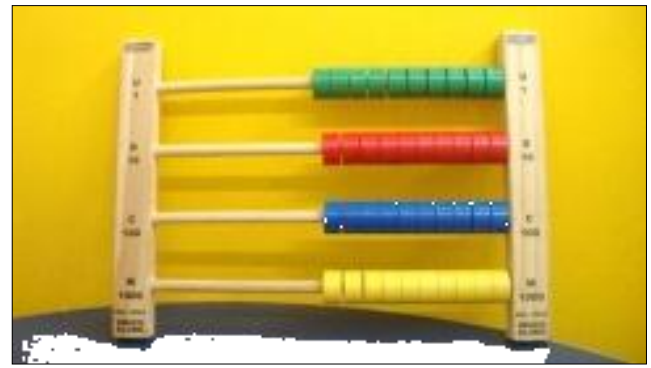

Figura 2 - Ábaco

\footnotetext{
${ }^{1}$ Dominó - Jogo de dominó com adição e subtração, que possuem regras iguai aos já conhecidos dominós clássicos. As peças possuem de um lado um resultado e do outro uma operação de modo que peças se unen quando o resultado contido numa das peças combina com a operação contida na outra peça. (http://bancodeatividades.blogspot.com/2009/11/pro-letramento-matematica5.html).

2 Ábaco - antigo instrumento de cálculo, formado por uma moldura com bastões ou arames paralelos, dispostos no sentido vertical, correspondentes cada um a uma posição digital (unidades, dezenas,...) e nos quais estão os elementos de contagem (fichas, bolas, contas,...) que podem fazer-se deslizar livremente.
} 


\subsection{1/ Análise das sessões de avaliação}

As primeiras sessões partiram dos eixos descritos por Weiss (1997) e estavam voltadas para conhecer a história de vida de P, sua dinâmica familiar, seu desenvolvimento motor e social, desde a gestação de sua mãe até sua idade atual. Além da verificação de sua relação com a escola, com as matérias de um modo geral, dando ênfase à matemática e seu conhecimento sobre os números naturais e decimais, as fórmulas básicas de adição e subtração, consciência numérica, bem como a relação entre números e quantidades. A sequência numérica, crescente e decrescente, sua atenção e concentração diante das atividades propostas. Enfim história da família nuclear e de suas primeiras aprendizagens.

A responsável foi muito atenciosa, respondeu a tudo que foi perguntado com muita boa vontade, puxando pela memória e se colocando a disposição para a qualquer momento se precisasse.

$\mathrm{O}$ aluno se envolveu com as atividades, demonstrou interesse e concentração na maior parte do tempo, lembrando que o mesmo estava medicado com o psicotrópico "metilfenidato".

Conforme DuPaul e Stoner (2007), a prescrição do psicotrópico é o tratamento mais comum para o TDAH, aproximadamente 1,5 milhão de crianças (mais de $4 \%$ da população em idade escolar) são tratadas com medicamentos psicotrópicos (por exemplo, metilfenidato). Acrescenta os autores que inúmeros estudos têm demonstrado, de modo coerente, a rápida melhora do funcionamento comportamental, acadêmico e social da maioria das crianças tratadas com substâncias estimulantes.

O resultado das primeiras sessões de avaliação foi muito produtivo, pois pudemos conhecer nosso sujeito, seu contexto e constituição familiar, as dificuldades passadas em sua vida, a perda de sua mãe, a convivência com o pai alcóolatra e finalmente a guarda da tia.

$\mathrm{P}$ foi muito habilidoso em vários aspectos durante o desenvolvimento do primeiro jogo. Compreendeu facilmente as regras, foi colaborador e rápido na primeira atividade, estava motivado e ganhou o jogo, o que o deixou ainda mais entusiasmado para o segundo.

Na segunda atividade, no jogo de subtração, logo no início já refletiu a incompreensão das regras que sustentam os algorítmos-padrão das operações atitméticas 
fundamentais, relacionada com a subtração. Souza (2009), afirma que a subtração de números naturais tem algumas particularidades que, no processo de ensino, podem determinar a qualidade de sua aprendizagem por parte dos alunos. Uma delas é a sua característica conceitual, de ser o primeiro conceito que aparece no rol de programas de ensino, que rompe com a grande trajetória do pensamento aditivo, fortemete aguçado desde os primeiros anos de vida.

A outra peculiaridade é de ordem algoritma. Sabe-se que o principio adotado no algoritmo da adição confunde-se com o da contagem, isto é, de agrupamentos, ou, popularmente denominado, de "vai um" e na subtração exige-se um “desmanchar" provisório do agrupamento para que a operação seja realziada a contento. Comumente, nos meios escolares, tal ideia é denominada de "pedir emprestado"

Portando, confirma a autora, para que o aluno consiga resolver com sucesso subtrações que envolvam esse "desmanchar provisório", é fundamental que compreenda o nosso sistema de numeração baseado em agrupamentos de dez em dez, por tratar-se da base 10 .

Para uma maior compreensão do aluno sobre o agrupamento de dez em dez do nosso sistema de numeração, foi utilizado como recurso didático, o ábaco. O que favoreceu-o na resolução dos cálculos até o final do jogo.

A partir dessas primeiras sessões foi possível levantar a hipótese de que o aluno não articulava muito bem os conteúdos que deveriam ter sido apreendidos por ele anteiromente, considerando sua idade e série. Conforme os Parâmetros Curriculares Nacionais, o assunto em questão é tema tratado no primeiro ciclo do ensino fundamental.

Diante dessas observações, propomos a intervenção psicopedagógica descrita a seguir, articulando a vivência em situações de investigação matemáticas e o uso de materiais didáticos. 


\section{2/ Sessões de intervenção}

\section{- Primeira Sessão de Intervenção}

A primeira sessão de intervenção aconteceu no dia 11 de outubro de 2011, na sala de apoio pedagógico e psicopedagógico, onde o aluno faz acompanhamento e teve duração de mais ou menos 90 minutos. Participaram dessa sessão, a pesquisadora e o sujeito de estudo.

\section{- Objetivo}

Dois aspectos foram objetivados nessa sessão: o primeiro foi verificar as dificuldades apresentadas por $\mathrm{P}$ em relação às aprendizagens sistematizadas pela escola, as competências do aluno com relação aos números decimais como, por exemplo, a notação da matemática, a realização de cálculos, o desenvolvimento do raciocínio lógico. E o segundo, o impacto da intervenção para o seu desenvolvimento.

\section{- Procedimentos}

Para a atividade, foi montado um mercadinho com alguns objetos colocados a venda, como por exemplo, bolsinhas coloridas com preços diferentes, carrinhos e balinhas. O mercado tinha um caixa com cédulas de mentirinha, de $R \$ 1,00, R \$ 2,00$, $\mathrm{R} \$ 5,00, \mathrm{R} \$ 10,00, \mathrm{R} \$ 20,00$ e $\mathrm{R} \$ 50,00$ e moedas de $\mathrm{R}$ \$ 0,5, R \$ 0,10 e R \$ 0,50, além de papel A4 e caneta esferográfica. P tomava conta do mercadinho.

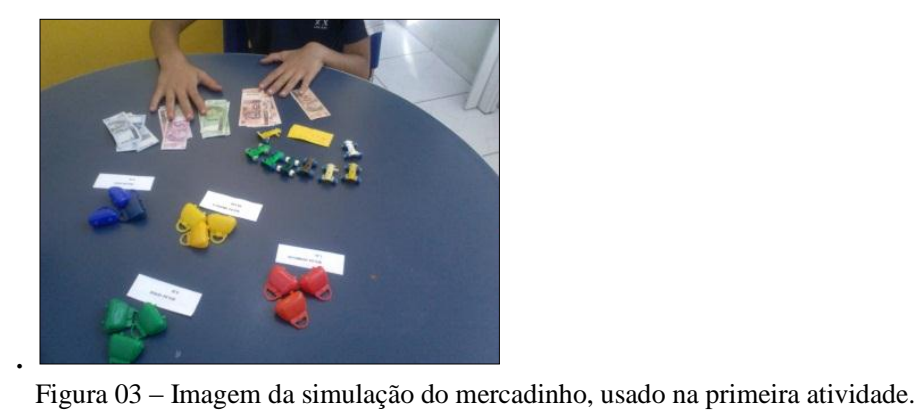

$\mathrm{Na}$ primeira atividade foram realizadas as seguintes compras no mercadinho:

1 bolsa vermelha $=\mathrm{R} \$ 7,20$ 
1 bolsa amarela $=\mathrm{R} \$ 4,80$

1 bolsa verde $=\mathrm{R} \$ 6,30$

3 carrinhos $=\mathrm{R} \$ 2,50$ cada

P foi solicitado a somar as compras para chegar ao valor total das mesmas e em seguida receber o pagamento devido. Primeiramente P fez o seguinte registro:

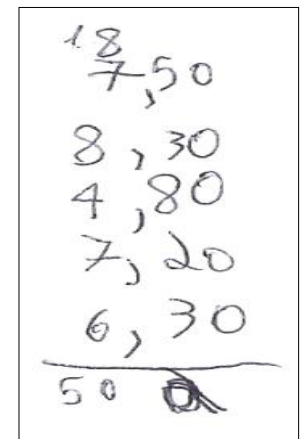

Figura 04 - Primeira notação apresentada por P durante a primeira sessão de intervenção.

Quando P organizou essa notação, foi questionado sobre o primeiro valor de $\mathrm{R} \$ 7,50$, ele ficou meio pensativo e respondeu que se cada carro custa dois e cinquenta: $\mathrm{R} \$ 2,50+2,50+2,50=\mathrm{R} \$ 7,50$, foi elogiado e em seguida foi solicitado a resolver a operação. Para fazer a notação, ele usou como apoio outra notação:

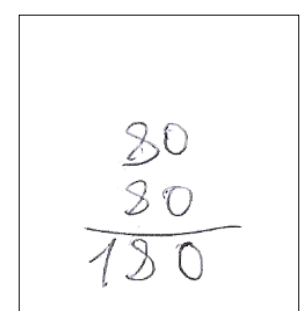

Figura 05 - Segunda notação, durante a primeira sessão de intervenção.

P foi questionado sobre o porquê de somar $80+80=180$ (figura 05). Ele respondeu: "por causa que ó... primeiro eu tenho que somar $50+30$, que vai dar 80 e depois mais 80, pra dar o resultado de 180", referindo-se a 0,30+0,20+30=0,80+ $0,80\left(1^{\mathrm{a}}, 2^{\mathrm{a}}, 3^{\mathrm{a}}\right.$ e $4^{\mathrm{a}}$. linha da primeira coluna, da direita para a esquerda), chegando ao valor de 180. $\mathrm{P}$ começou a errar a partir desse momento, pois, não chegou ao valor exato de 160, e explicou: “que vai obter o resultado" (apontando a segunda coluna da direita para a esquerda) "e uma parte desse resultado vai lá pra cima e ai vai tomar essa parte do resultado e vai somar: sete mais oito, mais quatro, mais dois", referindo-se a 
soma da referida coluna. Só que quando P transferiu o então 180 encontrado (figura 05) para sua primeira notação (figura 04), ele colocou o " 0 " embaixo dos decimais e colocou 18 na coluna dos inteiros.

Não chegando ao resultado correto. Uma intervenção nesse momento aconteceu, sugerindo que $\mathrm{P}$ repetisse a operação com esclarecimento de como deveria proceder. Assim P fez:

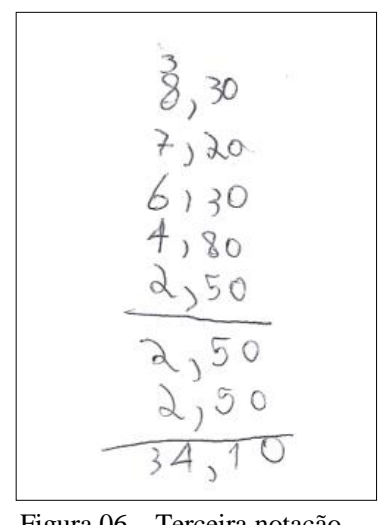

Produziu a notação acima, só que dessa vez, ao invés de colocar 7,50, dos valores dos carrinhos agregados, ele colocou separado, $2,50+250+2,50$. Procedeu-se uma intervenção nesse momento, sendo mostrado por onde ele deveria começar a somar. Ele tinha muita dificuldade na hora de somar números decimais, não organizava direito e as vírgulas o confundiam. Em um momento, ele começava a somar pelos decimais e em outro, pelos inteiros. Com a intermediação esclareceu-se quais os primeiros números a serem somados, começando pela última coluna da direita para a esquerda, e depois a segunda coluna, observando a vírgula e posteriormente a terceira e última.

Após a verificação correta do valor das compras realizadas no supermercado, foi solicitado que P cobrasse o valor devido. Para isso foi dado a ele, uma nota de $\mathrm{R} \$ 100,00$ e solicitado que ele desse o troco. P reclamou, já percebera sua dificuldade e sabia que não ia se sair bem por causa delas, o valor era muito alto, na sua concepção. Fez careta, se contorceu na cadeira e finalmente parou, olhou e perguntou: "Posso fazer trinta e quatro menos dez?", ele falou 10, quando na verdade queria falar 100. Faltava-lhe atenção. Foi respondido que ele poderia fazer como ele achava que seria o correto, foi lembrado que as compras tinham dado o valor de $\mathrm{R} \$ 34,10$ e ele 
tinha recebido $\mathrm{R} \$ 100,00$ e que deveria dar o troco corretamente. Dessa forma ele começou a desenvolver as notações seguintes:

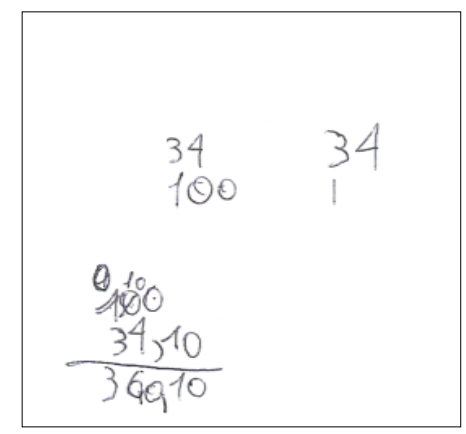

Figura 07 - Quarta notação

Primeiramente P colocou 34 em cima e 100 embaixo, invertendo a ordem dos números. Em seguida, percebendo sozinho o erro, começou uma nova notação e de novo começou errado e mais uma vez, sozinho percebeu que estava errado, parou um pouco, pensava alto, de repente perguntou: “Ai, eu esqueci! o que é mesmo que vêm primeiro, o 100 ou o 34?" Nada foi respondido, P continuava pensando alto e finalmente organizou a notação colocando a parcela maior no minuendo, só que não organizou corretamente, inteiro embaixo de inteiro e decimal embaixo de decimal. Em outras palavras, ele não tinha o entendimento que a casa dos décimos e dos centésimos estava vazia e que na verdade não compreendia o sistema de numeração decimal para os números não decimais.

Dessa forma P não conseguia chegar ao resultado correto e percebeu seu erro falando: "Eita, acho que fiz alguma coisa errada, porque o que tenho pra dar de troco é 36,10”. Foi questionado a ele: 36,10? P ficou pensativo e disse: “não, não sei”, a voz foi baixando, quase não dando para ouvir. O aluno mostrou dúvida, ele sabia que o valor não era aquele, por estar muito perto do valor das compras, e ele tinha um entendimento de aproximação. $\mathrm{P}$ parou, espreguiçou-se, olhou pra cima, como quem procurava uma resposta. Foi instigado a responder e disse: "Não sei" (risos acanhados), "é que deu 36 e é quase a mesma coisa de 34 e ai se somar 30+30, vai dar cento e pouco”. Foi falado para ele pensar então em outra maneira de resolver.

$\mathrm{P}$ abaixou a cabeça e ficou pensativo, levantou a cabeça e contava usando seus dedos silenciosamente. De repente ele falou: "o troco que tenho que dar é... setenta, setenta, setenta e cinco reais... ahhh não, setenta e seis reais" parou um pouquinho e continuou: "ah não!", olhou novamente para a notação que fez e falou: 
"setenta e cinco reais e dez centavos", falou e continuou a pensar alto (ele se aproximou mais do valor correto, quando fez os cálculos mentalmente do que quando fez no papel), ainda analisando, P falou: "setenta e cinco reais e oitenta centavos", mesmo muito próximo do valor, ele estava inseguro que quase não deu para ouvir o final da frase 'oitenta centavos", mas ele sabia que estava no caminho certo. Foi sugerido a ele que fizesse de outra forma, que começasse a dar o troco com o dinheiro, partindo do valor gasto nas compras, ao invés de usar o papel. Como o raciocínio estava indo bem e sua dificuldade era na armação da conta, foi mudada a estratégia para que ele pudesse chegar ao resultado correto com mais facilidade e segurança.

A primeira coisa que ele falou foi: “Mas, como vou fazer isso, se está tudo errado?" e começou a contar o dinheiro a partir de 34, foi corrigido e mesmo assim, continuou contando a partir de 34 inteiros, foi novamente corrigido, mas dessa vez foi dado uma dica que ele deveria usar as moedas para completar primeiro os centavos e só depois partir para o dinheiro de papel. Mais uma vez foi orientado a contar os centavos (as moedas), partindo dos 10 centavos dos 34,10, até chegar a 35,00, ele ficou olhando e se balançava na cadeira como que quisesse desistir da situação. Foi perguntado, quantos centavos ele deveria ter para completar um real, partindo de 10 centavos. $\mathrm{P}$ pegou as moedas e começou a contar: "vinte, trinta, quarenta, cinquenta, sessenta, setenta, oitenta...", o momento foi interrompido, pois estava faltando uma moeda de R $\$ 0,10$, a mesma foi providenciada e a atividade reiniciada.

No reinicio da atividade, foi explicado novamente para $\mathrm{P}$ que ele deveria dar o troco, partindo de $\mathrm{R} \$ 34,10$ e ele comentou: "(eu tenho que dar primeiro noventa centavos), e assim o fez, separou os noventa centavos e foi questionado pelo resto do troco, $\mathrm{P}$ olhou e deu um sorriso, olhou para o dinheirinho disposto sobre a mesa e começou pegando uma nota de $\mathrm{R} \$ 10,00$ e continuou olhando para o restante do dinheirinho, pensativo, pegou uma de $\mathrm{R} \$$ de $\mathrm{R} \$ 20,00$ e foi contando: "vinte mais dez é trinta”, pegou mais uma de R \$ 10,00 e somou: "quarenta”, pegando em seguida duas notas de R \$ 5,00, somando: “cinquenta” e mais duas notas de R \$ 5,00, "sessenta", continuando sua soma P pegou 5 notas de R 1,00 e foi somando: "sessenta e um, sessenta e dois, sessenta e três, sessenta e quatro e sessenta e cinco" e pegou duas notas de R \$2,00, somando: "sessenta e seis, sessenta e sete, sessenta e oito e sessenta e nove”, mesmo usando notas de $\mathrm{R} \$ 2,00$, P continuou a contar de um em um. 
Nesse momento $\mathrm{P}$ parou um pouco pensativo, olhava vagamente, balançando um lápis nas mãos, como se esperando que a resposta saísse desse movimento. Pegou uma nota de R \$ 2,00 e somou: "setenta e um, setenta e dois", ele não contou o número setenta.

Nesse momento houve uma intervenção, sugerindo ao aluno que ele trocasse as notas miúdas por uma nota de maior valor, para ficar melhor sua visualização e percepção de que o valor não estava correto. Foi sugerido que trocasse as notas de $\mathrm{R} \$ 10,00$ e de $\mathrm{R} \$ 20,00$, por uma de $\mathrm{R} \$ 50,00$, P olhou sorriu e falou: "é mesmo!" e começou a substituição, só que desfez tudo o que tinha feito voltando todas as notas para o lugar onde estavam e reiniciou separando a nota de $\mathrm{R} \$ 50,00$ contando: “cinquenta”, em seguida pegou uma nota de R \$20,00 e somou: "setenta”, pegou uma nota de R \$ 5,00 e somou: "setenta e cinco", pegou uma nota de $\mathrm{R} \$ 2,00$ e somou: "setenta e seis e sete", P ficou pensativo com a mão sobre o dinheiro e foi questionado: "Esse é o troco"? E ele respondeu sem tirar a mão de cima do dinheiro, pensativo e em dúvida: “Não, ainda não" e continuou no seu raciocínio pegando uma nota de R $\$ 1,00$ e colocando sobre o troco, falando: "sete... oito..." e falou cheio de insegurança: "é, eu acho que é" e continuou: "não, não, não pode. "Não sei" balançando negativamente a cabeça. Foi perguntado novamente a $\mathrm{P}$ quanto ele tinha que tirar de $\mathrm{R} \$ 100,00$.

Nesse momento, foi percebido um cansaço com relação à atividade, comum aos alunos TDAHs. Ele balançou várias vezes a cabeça de um lado pra o outro, fazendo um barulho com a boca, como quem desejasse sacudir os pensamentos. Mais uma vez foi informado sobre o valor da compra realizada, $\mathrm{R} \$ 34,10$ e sobre o valor de onde deveria ser cobrado e dado o troco, $\mathrm{R} \$ 100,00$ e de novo questionado de quanto seria esse troco. P se espertou, olhou para o dinheiro e falou: "vamos lá..., eu tenho que dar... setenta e... quatro. Não! Setenta e cinco reais”, trocando notas no troco. Foi questionado: "setenta e cinco reais?" $\mathrm{P}$ respondeu: "Não, setenta e cinco reais e noventa centavos". Foi perguntado então para $\mathrm{P}$ se $\mathrm{R} \$ 75,90+\mathrm{R} \$ 34,10$ era igual a $\mathrm{R} \$$ 100,00 e ele respondeu mexendo nas notas, como que confirmando: "dá", e foi questionado novamente: "Por quê?", sorrindo $\mathrm{P}$ se mexeu na cadeira, balbuciando algumas palavras, se sentia motivado quando instigado.

Foi feita uma explanação mais ampla para $\mathrm{P}$, demonstrando que ele já tinha separado noventa centavos e que se ele partisse dos trinta e quatro reais e dez centavos, 
era só ele ir contando até chegar em 100. Foi demonstrado para ele, como deveria proceder: "trinta e quatro e dez, mais dez, trinta e quatro e vinte, trinta e quatro e trinta, trinta e quatro e quarenta, trinta e quatro e cinquenta, trinta e quatro e sessenta, trinta e quatro e setenta, trinta e quatro e oitenta, trinta e quatro noventa e trinta e cinco" P olhava atentamente. Após a contagem dos centavos, a contagem continuou: "trinta e cinco" foi acrescentada uma nota de R\$ 5,00: "quarenta", foi acrescentado uma nota de R\$ 20,00: "sessenta" e nesse momento quando ele percebeu que ainda faltava a contagem de uma nota de cinquenta, mais os trocados, verificou que a soma estava errada.

Foi solicitado a $\mathrm{P}$, que ele informasse, qual era o valor que ele tinha separado para o troco, $\mathrm{P}$ contou novamente o valor e verificou que tinha $\mathrm{R} \$ 80,00 \mathrm{e}$ informou esse valor. Foi questionado mais uma vez de quanto seria o troco que ele deveria dar. P pegou novamente o dinheirinho e começou a contar as notas e enquanto contava falava: "setenta... cadê. hã, risos? Questionou! Pedro ria, divertia-se com a situação problema e continuou somando e falando: "setenta.., setenta... ahh! Muita coisa se tivesse colocado outra nota!" e continuou: "setenta e cinco" e confirmou "setenta e cinco", foi questionado: "Qual é o troco afinal"? E ele falou: "setenta e cinco e noventa", foi questionado novamente sobre o porquê de o troco ser $\mathrm{R} \$ 75,90$ e ele explicou: "Porque 75,90 + 34,10 são $R \$ 100,00 ”$, P foi elogiado em seu raciocínio e convidado a conferir o troco em conjunto: "Vamos lá"! Partindo de trinta e cinco reais e dez centavos, mais noventa centavos são iguais a trinta e cinco reais $(\mathrm{R} \$ 34,10+0,90$ $=\mathrm{R} \$ 35,00)$. Trinta e cinco reais, mais cinco é igual a quarenta, mais vinte, igual a sessenta e mais cinquenta, igual a cento e dez $(\mathrm{R} \$ 35+5=40+20=60+50,00=$ $110,00)$.

Foi confirmado a P que o troco continuava errado. Ele fez uma careta, deu um sorriso e falou ainda sorrindo como quem estava compreendendo onde foi o erro: "então tira cinco?" Foi falado que ele deveria descobrir sozinho, pensando mais sobre o problema. Foi reiterado que $34,10+75,90$ não era igual 100 e foi solicitado que ele fizesse a soma novamente. Ele balançou a cabeça afirmativamente e falou: "hum hum..., eu já sei. Vou fazer assim” retirando uma nota de $\mathrm{R} \$ 5,00$ : “que vai ficar 105, aí...” $\mathrm{P}$ parou e ficou pensando, ainda com a nota na mão, balbuciava, colocava a mão na cabeça e falou: "ai, mas como é que eu vou conseguir? E foi novamente explicado para 
ele fazer do jeito que já tinha sido demonstrado anteriormente, partindo dos 34,10 e somando até 100 , ratificando que troco se passa, partindo do valor das compras até o valor pago. O aluno demonstrava cansaço e impaciência e falou: “ah”!, mas, deu mais de 100 e eu não vou conseguir" Ficou parado, com a mão na cabeça, quando foi solicitado a começar de novo a soma, dessa vez com monitoramento.

$\mathrm{P}$ foi solicitado a ir acompanhando o raciocínio, a somar junto, dessa forma, foi perguntado quanto dava $34,10+0,90$ e ele respondeu: "trinta e cinco reais", em seguida ele foi convidado a continuar somando até chegar a 100, sempre instigado, chamado a participar com motivação. E novamente perguntado com mais 5 vai dar quanto? E ele respondeu: "quarenta", foi convidado a continuar: "o que mais? Continua somando". Com a cabeça meio baixa, $\mathrm{P}$ colocou mais uma nota de R $\$ 5,00 \mathrm{e}$ falou: "Quarenta e cinco" em seguida outra de R\$ 5,00 e falou: “cinquenta", parou um pouco e novamente instigado: "e o que mais?" $\mathrm{P}$ abriu finalmente um largo sorriso de satisfação e falou: “Mais 50”, pegando uma nota de $\mathrm{R} \$ 50,00$ "e cemmmm”, ele aplaudiu o resultado com entusiasmo. Após a euforia, $\mathrm{P}$ foi solicitado a verificar finalmente quanto daria de troco. Ele pegou o dinheiro e foi contando e falou: "Sessenta e cinco reais e noventa centavos".

Apesar da demora da atividade, do cansaço percebido, observamos a satisfação do aluno ao chegar ao resultado final de forma positiva.

O aluno foi elogiado e desafiado novamente a refletir sobre mais um problema. Dessa vez foi comprado:

1 bolsa azul 8,30

1 bolsa amarela 4,80

1 bolsa verde 6,30

P não estava mais tão empolgado com a atividade, estava cansado e refletia nele o desânimo e o desinteresse. Foi pedido para ele colaborar só com mais essa atividade, que já estava acabando e que ele tinha achado divertido no início. Sabe-se que para prender a atenção de um aluno TDAH por um tempo maior, a atividade tem que ser muito envolvente e interessante, se não desestimula e que as atividades precisam ser divididas para o aluno não dispersar e prender a atenção. Mas sabíamos também que o 
tempo que tínhamos com aluno era somente o que foi combinado, pois o mesmo estava estudando para as provas bimestrais na escola e precisa de tempo para se dedicar a isso.

$\mathrm{P}$ olhou, pensou, e pegou a caneta, abaixou a cabeça, desenvolvendo sem pestanejar a notação abaixo:

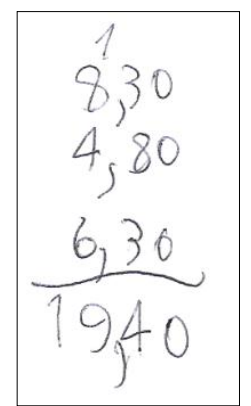

Figura $8-5^{\mathrm{a}}$ Notação

Erguendo-se e sem dúvida de seu registro, $\mathrm{P}$ informou: "Deu desenove reais e quarenta centavos". Foi elogiado e solicitado a descontar esse valor de uma nota de $\mathrm{R} \$ 100,00$. P olhou fixamente para cima, fez caretas e foi incentivado a fazer do jeito que lhe foi ensinado.

Surpreendentemente, $\mathrm{P}$ não pegou a caneta e nem o papel, se voltou diretamente para o dinheiro e começou a manuseá-lo, mexia de um lado para o outro as moedas, como se nesse mexer e remexer ele estivesse buscando a reposta, foi dado um tempinho a ele e depois convidado a prosseguir: "vamos lá? O total deu $R \$ 19,40$, quanto você tem que dar de troco?"

Ele foi colocando uma moeda ao lado da outra e foi falando: "quarenta, cinquenta, sessenta, setenta, oitenta, não, não" recomeçou a contagem: "cinquenta" pegando uma moeda de $\mathrm{R} \$ 0,10$ e continuou: "mais cinquenta, dá um real que dá vinte", procurou entre as cédulas do dinheirinho e falou: "trinta", juntando mais R\$ 10,00 às moedas e em seguida juntou mais R\$20,00 e falou "quarenta, cinquenta", se referindo a $\mathrm{R} \$ 20,00$, mas contando em dezenas.

$\mathrm{O}$ aluno se dispersava muito, a cada nota que ele ia pegar havia uma distração, num momento virava todas as notas com as caras para cima, em outro, separava por valores e assim a cada parada para ele organizar ou reorganizar quando voltava tinha que ser lembrado do problema. 
E foi assim nesse embaraço de cansaço e desatenção, que $\mathrm{P}$ pegou uma nota de $\mathrm{R} \$ 50,00$ e juntou ao troco, falando cheio de dúvidas e com a voz muito baixa: “cem?" e em seguida questionou no mesmo tom: “quanto é o teu troco?". Pecebeu-se a exaustão do aluno, percebeu-se também que a atividade tinha se estendido demais, e ainda, que nosso aluno Tdah estava sob efeito do medicamento e que pelo adiantado da hora, provavelmente o efeito do mesmo já não era igual como no inicio da atividade.

Mesmo comprendendo os problemas acima, precisavamos terminar a atividade e foi explicado mais uma vez ao aluno, que o valor da compra era de R $\$ 19,40$ e que ele teria que tirar esse valor de uma nota de $\mathrm{R} \$ 100,00$ e foi perguntado a ele: “Quanto você vai dar de troco?" e ele respondeu: “cem reais”e foi questionado se ele iria receber $R \$ 100,00$, como poderia dar também $R \$ 100,00$ de troco. P falou que não sabia, que estava difícil, balançava a cabeça, fazia caretas e reclava que foi passado uma atividade muito difícil pra ele. Foi informado que não era dificil, era muito super fácil, só precisava que ele parasse e pensasse um pouco sobre o problema e que ele era esperto e que estava muito próximo da solução.

P se voltou para o troco separado, pegou tudo na mão e falou: "super fácil! Ham, olha aqui ó" e começou a contar o dinheiro: "sessenta, setenta, oitenta" Referindo-se a 50+10+20. P parou um pouco, olhava para um lado e outro, estava analisando, contou o dinheiro novamente o mesmo modo que a anterior e finalmente compreendeu e falou: "ah! Deu 100. Tá qui seu troco" foi questionado de quanto era então o troco e falou: "oitenta reais e sessenta centavos".

Para finalizar a atividade foi sugerido que $\mathrm{P}$ confirmasse se o valor estava correto através de uma conta. De prontidão ele pegou o papel e a caneta, desenvolvendo a notação seguinta:

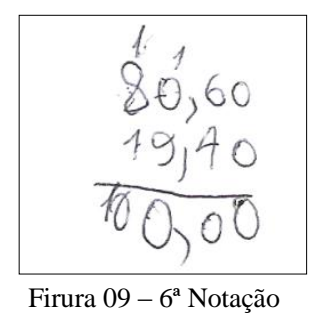

O aluno foi elogiado, e foi mostrado de forma muito positiva que percebíamos com clareza seu crescimento, apesar do cansaço. 
O término da sessão conviveu com um misto de emoção e cansaço, no que se refere à pesquisadora e ao aluno. Vivenciamos tanto esse momento importante de compreensão de conceitos, de interpretação de dados, de metacognição, como também uma demonstração clara de um aluno TDAH no ponto extremo da suas possibilidades e de atenção. 


\section{- Segunda Sessão de intervenção}

A quarta sessão aconteceu no dia 20 de outubro de 2011, na sala de apoio pedagógico e psicopedagógico, onde o aluno faz acompanhamento e teve duração de mais ou menos 60 minutos. Participaram dessa sessão, a pesquisadora e o sujeito de estudo.

\section{- Objetivo}

Escrever, ler e ordenar números com vírgula, Resolver situações problemas mentalmente e transcrevê-las para o papel, utilizando estratégias pessoais, cálculos convencionais e os conhecimentos adquiridos no quinto ano e nos anos anteriores.

\section{- Procedimentos}

Para essa atividade foi utilizado um encarte promocional de supermercado, dinheirinho de brinquedo, papel A-4, caneta esferográfica. A sessão foi toda filmada pela entrevistadora.

Foi feita uma simulação de um supermercado, onde P tinha que escolher os produtos a ser adquirido, somá-los e uma vez verificados o custo total dos mesmos, pagá-los com o dinheirinho, informando quanto ele teria de troco.

Primeiramente foi entregue ao aluno o encarte para ele se familiarizar com o mesmo, foi questionado se ele já tinha visto um encarte daquele, para quê servia o mesmo, se algum produto que constava no encarte, ele já tinha visto em sua casa e coisas do gênero. $\mathrm{P}$ sabia muito bem do que se tratava e para quê servia um encarte promocional.

Após essa familiarização de $\mathrm{P}$ com o encarte, foi informado como seria a atividade daquele dia. Lembrei a atividade anterior, onde ele era o dono do mercadinho e que eu comprava os produtos e ele passava o troco e que dessa vez, ele que ira ao supermercado. 


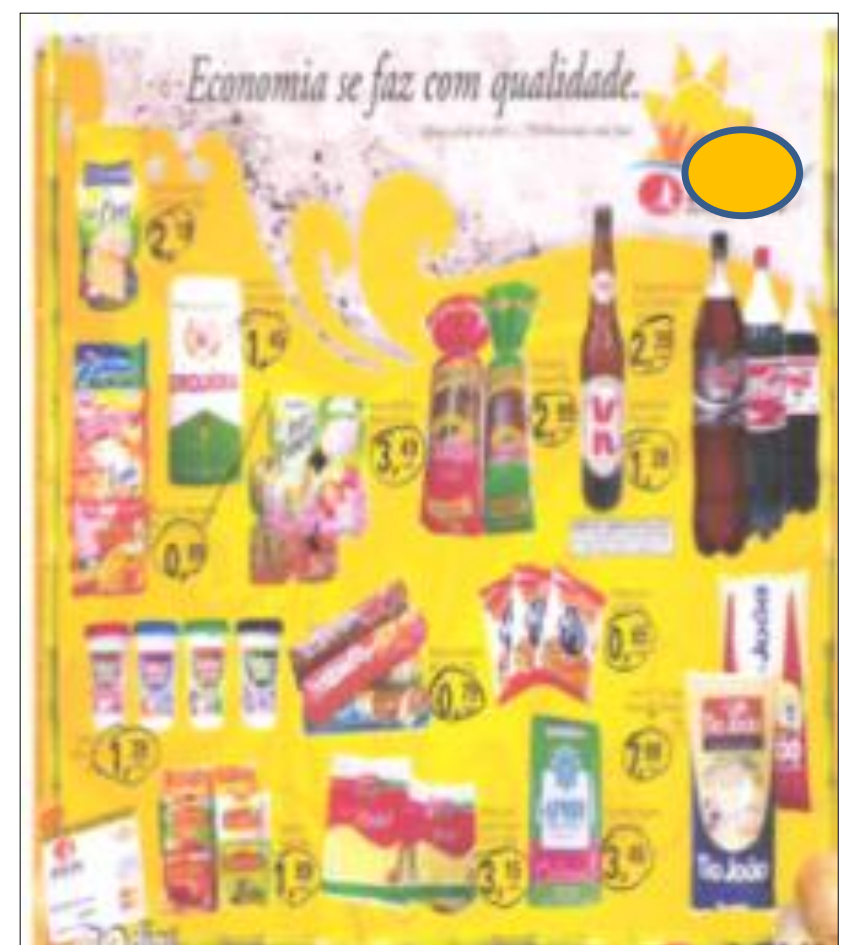

Figura 10 - Encarte usado na primeira atividade da segunda sessão de intervenção.

Foi sugerido então para a primeira atividade que $\mathrm{P}$ escolhesse dois produtos de sua preferência do encarte para comprar, foi pedido que ele fizesse um $\mathrm{x}$ ao lado do produto escolhido. Em seguida lhe foi entregue papel, para ele anotar o produto escolhido e o preço. $\mathrm{P}$ questionou como ele deveria fazer o $\mathrm{x}$, com dúvida sobre $\mathrm{o}$ procedimento. Foi informado que ele poderia fazer um círculo no preço do produto escolhido, ao invés de um x. Ele escolheu biscoito e bolo de coco e novamente foi solicitado que ele anotasse os produtos escolhidos. P assim procedeu: Anotou na folha os produtos e do lado de cada produto o respectivo preço. Foi questionado então, quanto ele iria gastar com esses dois produtos e sugerido a ele que fizesse o calculo para essa verificação. P já tinha sido orientado na sessão anterior de como deveria organizar a adição e o fez corretamente, colocando vírgula debaixo de vírgula, conforme descrição abaixo.

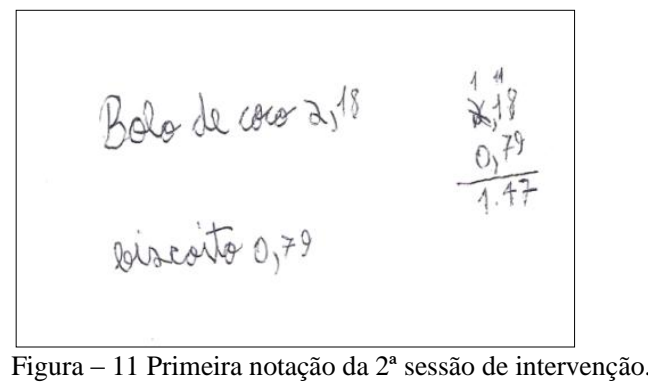


Apesar da correta organização, P confundiu-se na hora da adição e subtraiu ao invés de adicionar e mesmo adicionando, não conseguiu chegar ao resultado correto. Ele demorou um pouco na atividade, ficou pensativo, tinha dúvidas, mas não perguntou. Quando terminou, olhou para sua notação e falou: "peraí..." perguntado sobre o que tinha havido, ele respondeu: "errei". Foi perguntado o que ele tinha errado, se ele queria explicar o que houve, ele sem falar nada, começou imediatamente a fazer outro registro, agora um pouco mais rápido, como quem estivesse com pressa de responder ao questionamento demostrando e não falando.

Foi questionado mais uma vez sobre o erro na notação anterior e então ele explicou que tinha subtraído ao invés de somar. Nesse momento, quando P foi explicar o erro, percebeu que já tinha errado a segunda notação e partiu para a terceira.

Na segunda notação, $\mathrm{P}$ colocou 0,78 ao invés de 0,79 , quando fez a terceira, cometeu o mesmo erro, colocou 0,78 de novo no lugar de 0,79 , percebendo sozinho seu erro, P partiu para a quarta notação. Quando terminou, foi pedido para ele explicar os erros cometidos e ele começou da primeira notação, explicando que tinha diminuído, que a segunda ele tinha colocado 8 no lugar dos 9 e a terceira também tinha cometido o mesmo erro da segunda.

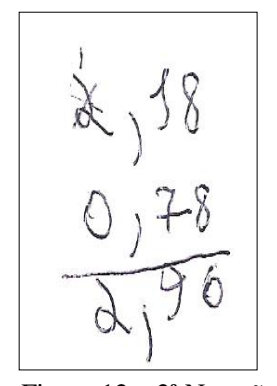

Figura $12-2^{\mathrm{a}}$ Notação

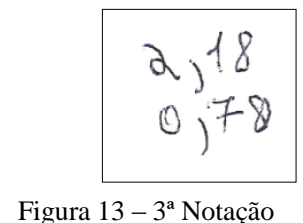

Figura $13-3^{\mathrm{a}}$ Notação

Foi questionado então, sobre a quarta notação, se estava certa e como ele tinha realizado a notacao. $\mathrm{P}$ foi mostrando como tinha chegado ao resultado: "Primeiro somei $8+9$, que dá 17 e ai coloca o 7 aqui (apontando corretamente para última coluna da direita para a esquerda,) e o 1 coloca lá em cima" (apontando novamente para a coluna ao lado), só que o número 1 não estava lá, como ele tinha falado, ou seja, ele pensou, mas não o colocou. Assim que percebeu sua desatenção, imediatamente colocou o número e continuou sua explicação: “Aí eu somei 7, 8 e 9, e aqui dá 2”, (Apontando para a terceira e última coluna da direita para a esquerda). 


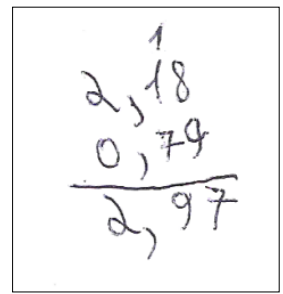

Figura $14-4^{\mathrm{a}}$ notação

Após $\mathrm{P}$ ter chegado ao resultado correto, foi perguntado quanto ele tinha gasto em suas compras e ele respondeu: "dois e noventa e sete", e foi questionado novamente: "dois o quê?" e ele respondeu: "Dois reais e noventa e sete centavos". Em seguida P foi solicitado a pensar sobre a seguinte situação: "Suponha que você leve para esse Supermercado R\$ 5,00 para pagar suas compras, quando lhe sobraria de troco?" Após ser questionado, P imediatamente já começou sua quinta notação, de cabeça muito baixa, foi preciso inclusive pedir para ele levantar um pouco a cabeça.

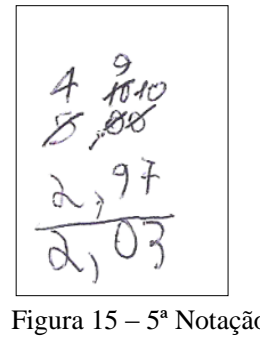

Quando P levantou a cabeça, já foi falando: "dois reais e três centavos". Solicitado a explicar, e recebendo pistas da situação, ele falou que gastaria R \$ 2,97 no Supermercado, pagaria com $\mathrm{R} \$ 5,00$ e receberia 2,03, questionado novamente: "dois reais e três centavos, de quê?", e ele responder: "de troco". Foi elogiado e nesse momento foi dada uma pausa para água e descanso para a próxima atividade. (Foi percebido na sessão anterior a necessidade de se proceder um intervalo para evitar o cansaço e o desinteresse)

Ao retornar, a atividade seguinte foi logo iniciada com a solicitação de uma nova compra no supermercado, dessa fez $\mathrm{P}$ deveria escolher cinco produtos do encarte para comprar. $\mathrm{P}$ ficou olhando um pouco para o encarte, em seguida pegou a caneta e começou calmamente a escolher os produtos.

Nossa hipótese era de que a atividade era tão diferente das vivenciadas por ele em ambiente escolar que lhe causava grande prazer. P gostava do que estava fazendo 
e queria aproveitar aquele momento ao máximo. Era como se ele pudesse mostrar as coisas que sabia sem cobrança.

Depois de quase 02 minutos, foi perguntado se ele já tinha escolhido, confirmando com a cabeça, foi perguntado novamente sobre os produtos que tinha escolhido. Ele responde circulando com a caneta os seguintes produtos: macarrão instantâneo, arroz, refrigerante, pão e iogurte. Foi perguntado então quanto ele iria gastar dessa vez em suas compras.

$\mathrm{P}$ colocou os valores ordenadamente, um embaixo do outro, sem os nomes dos respectivos produtos. Como o primeiro numeral colocado foi 7,50, foi perguntado a que produto se referia esse primeiro valor e ele responde que se referia ao "feijão", novamente foi questionado se tinha feijão em suas compras e ele respondeu: " $a h$ não! $E$ do arroz", foi solicitado então a colocar ao lado de cada valor o produto correspondente. Houve uma colaboração nesse momento com P, por uma dificuldade de copiar os nomes dos produtos e escrevê-los aos seus valores respectivos.

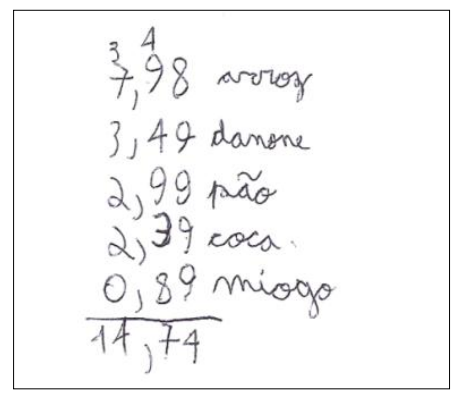

Figura $16-1^{\text {a }}$ Notação da $2^{\text {a }}$ Atividade

Após fazer a primeira notação dessa segunda atividade, $\mathrm{P}$ foi questionado sobre quanto gastaria para realizar suas compras. Em seguida ao questionamento, sem falar nada, pegou a caneta e de cabeça baixa, começou a efetuar a adição. Levantando a cabeça, como na vez anterior, falou: "catorze reais e setenta e quatro centavos". Perguntado se ele tinha certeza de que o resultado estava correto, ele falou que sim. Acredito que ele fez a soma corretamente, na cabeça, o calculo foi concluído e corretamente, o que não foi certo foi o valor colocado no total(a escrita do valor), 14 ao invés de 17 . Foi convidado a realizar novamente o registro e concordou iniciando a $2^{\mathrm{a}}$ notação. 


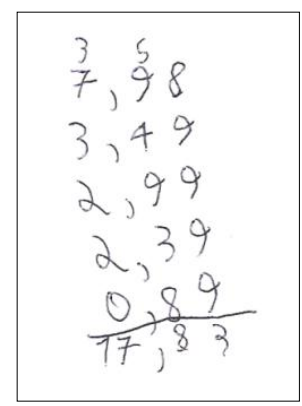

Figura 17 - Segunda Notação da $2^{\mathrm{a}}$ atividade

No momento do registro da citada notação, foi perguntado a $\mathrm{P}$ se ele achava que nas atividades que têm mais números, ele se atrapalhava, ele respondeu que não sabia. Foi insistido, perguntando se ele não notava nada, $\mathrm{P}$ balançou a cabeça afirmativamente. Ele se mantinha concentrado, realizando a soma, de cabeça meio abaixada. Quando a levantou falou: “dezessete reais e oitenta e três centavos". Foi informado a $\mathrm{P}$ que havia alguma coisa errada no seu registro. Não esperou nenhum comando e já começou a terceira notação. Foi informado que faria esse registro com monitoramento até o final. Ele só confirmou com a cabeça e continuou o registro.

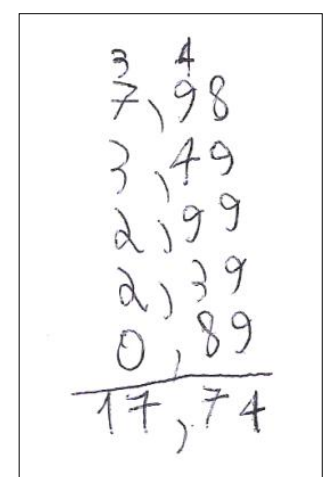

Figura 18 - Terceira Notação da $2^{\mathrm{a}}$ atividade

Logo que P organizou a notação, lhe foi perguntado quantos nove ele tinha na notação, ele respondeu que tinha quatro noves, foi então perguntado, quanto era $4 \mathrm{X}$ 9 e o questionamento continuou, sendo perguntado se não era mais fácil fazer uma multiplicação quando tinha vários números iguais e $\mathrm{P}$ respondeu: "mas vai dar a mesma coisa se a gente somar?", foi confirmado a colocação dele, mas foi colocado que para simplificar, ao invés de somar 9+9+9+9, seria mais fácil multiplicar 4X9 e ele respondeu: "Não, prefiro 9x4", então foi solicitado para que fizesse multiplicando ao invés de somar, foi sugerido também que ele poderia fazer os cálculos dessa multiplicação ao lado, mas ele falou que não precisava, fico quieto, olhando para os 
número e falou: "trinta e seis", $\mathrm{P}$ foi questionado como ele tinha feito essa conta de multiplicar somente na cabeça, sem usar caneta ou papel e ele respondeu: "nove vezes quatro", foi pedido detalhes dele e ele complementou: "quatro, oito, doze, dezesseis, vinte, vinte e quatro, vinte e oito, trinta e dois e trinta e seis", foi elogiado e solicitado a somar os $36+8$ e ele respondeu: "quarenta e quatro", foi elogiado novamente e recebeu a indicação de em qual coluna ele deveria colocar os algoritmos e assim o fez.

$\mathrm{Na}$ segunda coluna, foi sugerido a $\mathrm{P}$ que ele começasse a somar os números maiores primeiro, por exemplo, $9+9$ e ele de prontidão respondeu que era 18 e foi perguntado: “ $18+8$ ?" e respondeu sem pestanejar " 26 ”, “vinte e sei mais 4?” ele respondeu 30, “30 + 4?”, ele respondeu “34”, “ e mais 3?”, ele respondeu: “37”, enquanto respondia oralmente, escrevia o resultado corretamente e na coluna adequada.

Passou-se então para a última coluna, a dos inteiros e foi perguntado a $\mathrm{P}$ quanto era $7+3$, ele não respondeu oralmente, mas foi fazendo os cálculos e sozinho chegou ao resultado correto. Foi elogiado e questionado sobre o valor total das compras escolhidas no encarte do Supermercado e foi respondido: "dezessete reais e setenta e quatro centavos".

Foi informado a $\mathrm{P}$ que ele receberia $\mathrm{R} \$ 50,00$ para efetuar o pagamento das compras no Supermercado e ele deveria dizer quanto receberia de troco. P fez caretas, se remexeu na cadeira, como quem quisesse fugir da atividade, mas sorriu, como se sentindo desafiado. Pegou a caneta e começou a desenvolver seu raciocínio e no término, não muito demorado descreveu a notação abaixo e falou: “(trinta e dois reais $e$ vinte e seis centavos)".

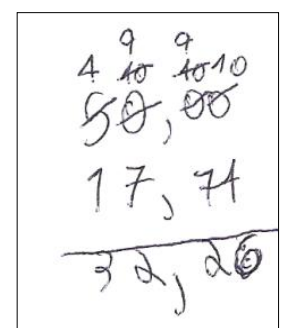

Figura 19 - Quarta Notação da segunda atividade.

$\mathrm{P}$ foi elogiado e mais uma vez instigado. Foi questionado se com os $\mathrm{R} \$$ 50,00 que levou ao Supermercado, ele tivesse pagado as duas compras que fez (figura 16 e figura 18), quanto ele teria gastado nas compras e quanto ele receberia de troco. $\mathrm{P}$ recebeu uma nova folha e se voltou para o papel começando mais uma vez seu registro. 
Começou com os algoritmos 2,7, pensou um pouco e recomeçou colocando 17,7 na primeira parcela e em seguida colocou 2,97 na segunda, conforme figura abaixo.

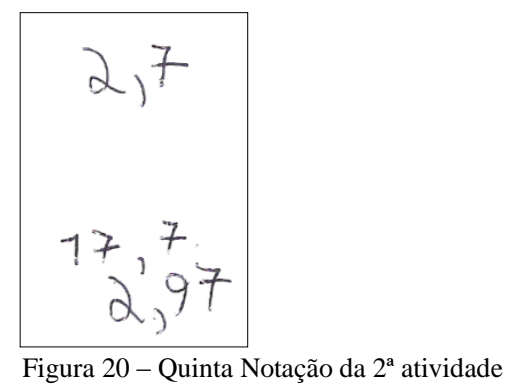

Como estava demorando muito, foi questionado sobre o que estava fazendo e se estava precisando de ajuda. P comentou que nem ele mesmo sabia o que estava fazendo, nesse momento foi questionado o porquê da notação que ele estava fazendo, e justificou que iria subtrair o valor gasto no supermercado dos $\mathrm{R} \$ 50,00$ recebidos, conforme descrição abaixo:

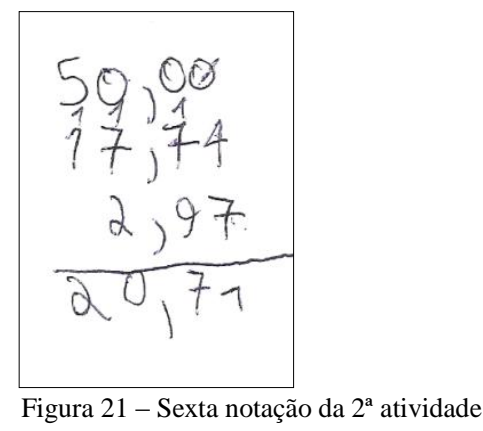

Foi questionado novamente de que maneira organizaria a subtração. Ele não respondeu, efetuou a soma das duas compras do supermercado e apesar de ter colocado o algoritmo 50 na primeira parcela, não à considerou, colocando o resultado da soma corretamente. Questionado novamente sobre a organização da soma, P continou sem responder e voltado para o papel organizou a notação abaixo:

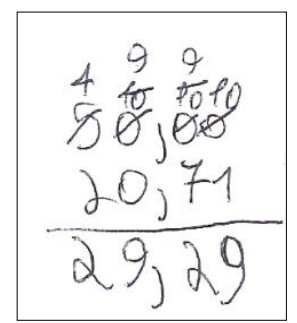

Figura 22 - Sétima notação da $2^{\mathrm{a}}$ atividade 
P registrou corretamente as compras e corretamente também passou o troco. Foi elogiado e convidado a analisar o que ainda daria para ser comprado com a sobra. Pegou novamente a caneta e começou a circular alguns produtos do encarte. Após a escolha dos produtos, ele foi solicitados a transcrevê-los no papel e assim o fez:

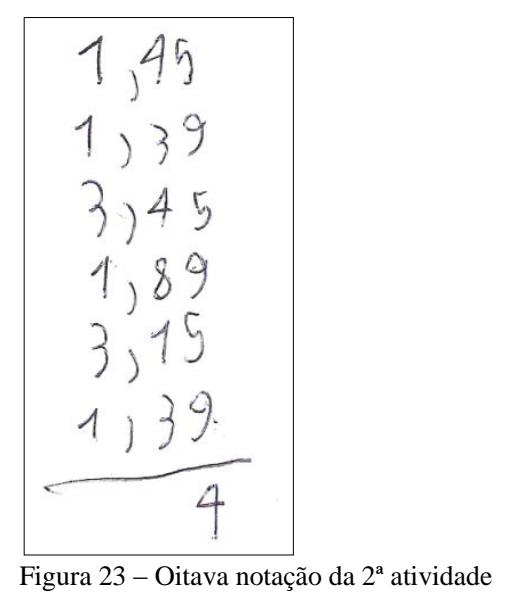

Dessa vez não colocou os nomes dos produtos, somente os valores dos mesmos e quando somou a primeira coluna, sozinho percebeu que tinha errado e imediatamente sem falar nada e de cabeça baixa, começou novo registro.

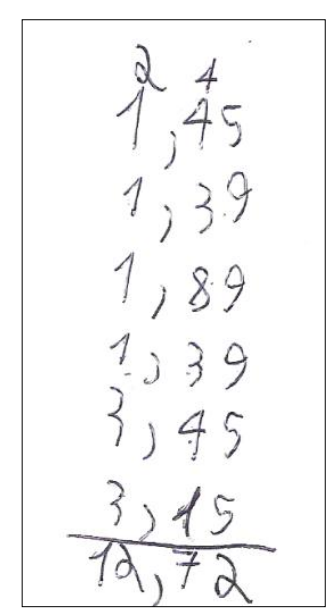

Figura 24 - Nova notação da $2^{\mathrm{a}}$ atividade

P só levantou a cabeça quando terminou e foi logo dizendo: "doze reais e setenta e dois centavos". Foi conferido o valor e a forma que foi realizado o registro em conjunto com $\mathrm{P}$ e depois de ser elogiado foi explicado que ainda tinha lhe sobrado um troco das duas primeiras compras do encarte no valor de $\mathrm{R} \$ 29,29$ e que desse valor ele 
teria que tirar as novas compras. $\mathrm{O}$ aluno mais uma vez sem nada responder, virou-se para o papel e efetuou o registro abaixo:

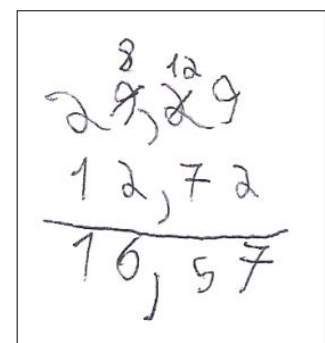

Figura 25 - Décima Notação da $2^{\mathrm{a}}$ atividade

$\mathrm{P}$ calculou corretamente, com desenvoltura de quem compreendera muito bem a atividade proposta, foi elogiado e questionado se ainda queria comprar mais alguma coisa ou se preferia levar o troco para casa. Ele falou que estava cansado e preferia levar o troco pra casa.

No término da atividade, ambos estávamos felizes pelos resultados obtidos depois dos caminhos trilhados. Apesar de $\mathrm{P}$ preferir parar a atividade, era claro sua satisfação pelo desenvolvimento de uma atividade diferente de tudo que ele já tinha feito, com materiais tão diferentes e estimulantes para o aluno. 


\section{V/ Discussão geral dos resultados das sessões de Intervenção}

A vivência nas sessões de intervenção possibilitou-nos muitos entendimentos. Alguns de natureza didática, outros conceituais, outros organizacionais. Tudo isso mostra-nos o valor do método adotado e sua pertinência para estudos que visam o desenvolvimento de professores (pesquisadores) e alunos. Diante disso, optamos por construir esse item privilegiando os aspectos pontuados acima, transitando de uma sessão a outra.

Ao longo das intervenções, percebemos melhoras significativas com relação à compreensão do aluno, referente aos números decimais, sua organização em unidades, dezenas e centenas, a adição e subtração dos mesmos, como também a realização de cálculos mentais.

E para nós compreender todo o processo de desenvolvimento do aluno, e especificamente do aluno tdah, suas particularidades e dificuldades, nos favoreceu para o entendimento deste com relação à matemática.

Uma vez que este aluno apresenta dificuldade com as funções executiva, Rhode e Matos (2003), dificultando assim, sua compreensão, a auto-organização e seu desempenho autônomo em atividades escolares. Levando-nos a constatar que a mediação facilitou muito o processo, como também o material utilizado. Uma vez que optamos por trabalhar com materiais que fazem parte do cotidiano do aluno e com situações que podem ser observadas em seu contexto de dia-a-dia, Chernay (2001).

Os resultados apontam que as avaliações e intervenções propiciaram a tomada de consciência e contribuíram para o desenvolvimento de novas competências conceituais, como também a confirmação que essa aquisição poderá ser aplicada em sua vida, independente da escola, Brousseau (1996). O que para Nunes, (1991), pode ser o ponto de partida para ensinar matemática na escola, independente de o aluno ter alguma dificuldade ou não. Uma vez que ao desenvolver uma atividade de forma diferenciada para atender um aluno em particular acaba favorecendo a todos sem distinção, fazendo com que o aluno se sinta incluso e fazendo parte do processo de ensino-aprendizagem.

Conforme Pina Neves (2008), o ensino de matemática, continua na sua maioria, sendo realizado pela transmissão de saberes prontos pelos professores aos alunos, em todos os níveis de ensino; que os professores da Educação Básica, na maior 
parte dos casos, são usuários de regras e vivenciaram em sua formação inicial, um ensino também pautado na transmissão de saberes.

O entusiasmo demostrado pelo aluno nos fez confirmar o quanto esse ensino está engessado. Em sala de aula, o professor, na sua maioria, "transmite" e os alunos "recebem" os conteúdos, Chaga (2004), em atividades mecanizadas, exigindo dos alunos somente memorização.

Aprender é uma busca interminável e permanente de discernimento e poder, conforme PFROMM (1987) é a passagem de um estado inicial à independência. Independência essa, já comentada acima e muito mais difícil de ser conquistada por um aluno TDAH.

Sendo assim ressaltamos a importância não somente do material didático utilizado, mas também da mediação. De um olhar amplo que conforme Visca (1991), para um mundo de possibilidades, diante de um indivíduo e suas particularidades e características individuais.

Visca (1987) acrescenta que a aprendizagem depende de uma estrutura onde envolva o cognitivo, o afetivo e o social, na qual esteja indissociavelmente ligada a algum aspecto desses três elementos. Dessa forma a inteligência se constrói a partir da interação do sujeito e as circunstâncias sociais.

Percebemos esse fato em nosso estudo e também que o aluno TDAH tem capacidade de aprender, só que aprende diferente dos demais. E que é necessário, antes de tudo, que os professores resignifiquem o termo "aprender", compreendendo assim como Fávero (2005) que há um processo de mudança tanto do aluno, como dos professores, o que significa que os sujeitos estão em desenvolvimento, evoluindo, ascendendo, portanto construindo seu desenvolvimento. 


\section{VI/ Considerações Finais}

O presente trabalho apresenta uma explanação referencial sobre a relação dos alunos TDAH e as dificuldades com a matemática, particularmente com os números decimais. Um recorte dentro da ampla questão da aprendizagem humana, em um estudo de caso, com aluno TDAH de 11 anos, cursando o $5^{\circ}$ do ensino fundamental, de uma escolar particular de Brasília e de um acompanhamento pedagógico e psicopedagógico.

Nosso objetivo foi observar os aspectos que levam as dificuldades escolares na disciplina de matemática e que podem ser detectado através do diagnóstico psicopedagógico, avaliando e intervindo em sessões amparadas por conceituações matemáticas e materiais didáticos.

No processo de avaliação e investigação, foi utilizada uma proposta metodológica diferenciada. Utilizaram-se atividades relacionadas com a vida do aluno, atividades que normalmente seriam usadas no seu dia-a-dia. Diferentemente das propostas na sala de aula do aluno, mecanizadas e sem significado para ele.

Com o material didático empregado, os jogos, o mercadinho, o ábaco etc., a situação foi outra, as relações numéricas abstratas passaram a ter forma concreta, facilitando a compreensão dos algoritmos, um surpreendente desenvolvimento no raciocínio e um aprendizado mais agradável.

Percebemos grande motivação do aluno no desenvolvimento das atividades. Como as mesmas foram muito contextualizadas e desafiantes, o aluno foi levado a entendê-las como uma atividade mais lúdica do que pedagógica.

$\mathrm{P}$ encerrou a última sessão entendendo os caminhos a serem tomados na resolução de problemas, principalmente os que envolviam a subtração, de números decimais, uma das dificuldades detectada desde o início dos encontros.

Inferimos que ele ainda está em processo de desenvolvimento, muito tem a ser trabalhado para atingir a proficiência dos cálculos dos números decimais, mental e lógico. Muito também a se fazer para esse aluno TDAH consiga estratégias para vencer suas dificuldades, independente de qualquer disciplina.

Comungo com Visca (1997), quando diz que a aprendizagem para uma pessoa abre caminho da vida, do mundo das possibilidades até de ser feliz. A vivência nesse trabalho ampliou esse entendimento acerca do desenvolvimento humano e profissional. Avaliamos que desenvolvemos novas competências a cada nova sessão. 
Nossa capacidade de ouvir, de refletir, de controlar ansiedade e principalmente de analisar, foi expandida sobremaneira durante o trabalho e com certeza esse crescimento se deu em conjunto.

Embora o número de sessões tenha sido reduzido, o trabalho foi apurado pelas horas trabalhadas, pontuando nossa observação de que o resultado poderia ser ainda melhor se tivéssemos trabalhado com maior número de sessões e tempo reduzido.

Entendemos que um trabalho dessa natureza muito nos ensina sobre as possibilidades de se promover a aprendizagem da matemática, independente de ser aluno TDAH ou não e defender a proposta (nossa) e a forma que ela pode ser trabalhada em sala de aula.

A intervenção nos auxiliou nessa constatação e no entendimento da importância de as atividades de matemática estar relacionadas com o cotidiano do aluno e ainda que esse aluno seja olhado na sua singularidade, compreendendo que cada um aprende de uma formar diferente e que os professores deveriam estar atentos a isso.

Avaliamos que outros trabalhos nessa perspectiva devam ser realizados, ampliando o tempo de intervenção, as possibilidades de registros e a articulação com outros pesquisadores. 


\section{VII/ Referências}

Associação de Psicopedagogia, site: www.abpp.com.br.

Barkley, A. Russell e Murphy, R. Kevin. (2008). Transtorno de Déficit de Atenção/Hiperatividade - Exercícios clínicos. Porto Alegre: Artmed.

BRASIL, Ministério da Educação e do Desporto. Secretaria de Educação Fundamental. Parâmetros Curriculares Nacionais: Matemática. Brasília, DF, 1997/1998.

Brousseau, G. (1996). Os diferentes papéis do professor. Em C. Parra \& I. Saiz.(Orgs.), Didática da matemática: reflexões psicopedagógicas. Porto Alegre: Artes Médicas.

Chaga, Elza Marisa Paiva de Figueiredo. (2004). Fracassos do Ensino da matemática: Contribuições ao debate. Teórico para uma educação inclusiva. III Seminário Internacional Sociedade Inclusiva. Ações Inclusivas de Sucesso. BH,.

Charnay, R. (2001). Aprendendo (com) a resolução de problemas. Inn: Parra. C. Didática da Matemática: reflexões psicopedagógicas. Porto Alegre: Artes Médicas.

Correa, Jane e MacLean, Morag. (1999). Era uma vez um vilão chamado Matemática: Um estudo intercultural da dificuldade atribuída à matemática. Psicol. Reflex. Crit, vol. 12, nr. 1, p. 173 - 194. ISSN 0102-7972.

DuPaul J. George e Stoner Gary. (2007). TDAH nas escolas: Estratégias de Avaliação e Intervenção. (Tradução Dayse Batista). São Paulo:M. Books.

Fávero, Maria Helena. (2005). Psicologia e conhecimento: Subsídios da psicologia do desenvolvimento para a análise de ensinar e aprender. Brasília. UNB.

Kiguel, S. M. (1991). Abordagem psicopedagógica da aprendizagem. Porto Alegre: Artes Médicas.

Neves, Regina da Silva Pina. (2008). A divisão e os números racionais: Uma pesquisa de intervenção psicopedagógica sobre o desenvolvimento de competências conceituais de alunos e professores. Tese de Doutorado. Universidade de Brasília. Brasília. 
Nunes, Terezinha e Bryant Peter. (1997). Crianças fazendo matemática, Porto Alegre: Artes Médicas.

Moreira, Eline Dias. (2007). A importância da afetividade no processo de ensino aprendizagem de matemática. Tese de Mestrado. Pontifícia Universidade Católica de São Paulo. São Paulo.

PFROMM, Netto, Samuel. (1987). Psicologia da Aprendizagem e do Ensino. São Paulo, SP: USP.

Rhode, Luiz Augusto; Mattos, Paulo \& cols. (2003). Princípios de práticas em Transtorno de Déficit de Atenção/hiperatividade. Porto Alegre: Artmed.

Sousa, Isabela Mascarenhas Antoniutti de. (2009). As Mediações no processo de apropriação do conceito de subtração: Visão dos Professores das séries iniciais do ensino fundamental. IX Congresso Nacional de Educação - Educere - III Encontro Sul Brasileiro de Psicopedagogia. PUC. PR.

Visca, Jorge. (1987). Clínica Psicopedagógica: Epistemologia Convergente. Porto Alegre, Artes Médicas.

Visca, Jorge. (1991). Psicopedagogia: novas contribuições. Nova Fronteira

Weiss, Maria Lúcia L. (1997). Psicopedagogia Clínica: Uma visão diagnóstica dos problemas de aprendizagem escolar. Rio de Janeiro. DP\&A. 